\title{
A large, pathological skeleton of Smilosuchus gregorii (Archosauriformes: Phytosauria) from the Upper Triassic of Arizona, U.S.A., with discussion of the paleobiological implications of paleopathology in fossil archosauromorphs
}

\author{
Andrew B. Heckert, Tabitha C. Viner, and Matthew T. Carrano
}

\begin{abstract}
Phytosaurs were a widespread clade of Triassic predatory archosauriforms whose skull anatomy is well known, but whose paleobiology is underexplored. Here we report on a well-preserved specimen from Adamanian (early-mid-Norian) strata in Arizona that includes not only the skull and lower jaws but much of the postcranial skeleton, which exhibits extensive evidence of pathologies. This specimen has a complex taxonomic history, and we verify its referral to Smilosuchus gregorii based on multiple cranial characters.

The shafts of eight limb bones preserve extensive exostoses-more paleopathological elements than in any other Triassic archosauromorph. These exostoses are often centered on cavitations reminiscent of draining tracts. Extensive, irregular, proliferative lesions have completely engulfed the left deltopectoral crest and thoroughly altered the architecture of both femora. The animal's presumed low metabolic rate would have allowed several months of lesion progression before it died of either nutritional deficiency or systemic infection. This is the fourth, and by far the most extensive, report of pathology in a phytosaur, and only the eighth in a non-dinosaurian Triassic archosauromorph.

The character and location of the lesions evokes aspects of both osteomyelitis and hypertrophic osteopathy-though neither is fully consistent with the changes present, nor are these conditions well-explored in extant reptiles. The most likely cause of the pathologies exhibited here is osteomyelitis; indeed, this specimen bears more osteomyelitis-like paleopathological elements than any other fossil archosaur.
\end{abstract}

Andrew B. Heckert. Department of Geological and Environmental Sciences, Appalachian State University, ASU Box 32067, Boone, North Carolina 28608-2067 USA. heckertab@appstate.edu

Tabitha C. Viner. USFWS National Fish and Wildlife Forensic Laboratory, 1490 E. Main St. Ashland, Oregon 97520, USA. tabitha_viner@fws.gov

Matthew T. Carrano. Department of Paleobiology, P.O. Box 37012, MRC 121, Smithsonian Institution, Washington, DC 20013-7012, USA. carranom@si.edu

Heckert, Andrew B., Viner, Tabitha C., and Carrano, Matthew T. 2021. A large, pathological skeleton of Smilosuchus gregorii (Archosauriformes: Phytosauria) from the Upper Triassic of Arizona, U.S.A., with discussion of the paleobiological implications of paleopathology in fossil archosauromorphs. Palaeontologia Electronica, 24(2):a21. https://doi.org/10.26879/1123

palaeo-electronica.org/content/2021/3385-pathological-phytosaur

Copyright: June 2021 Society of Vertebrate Paleontology.

This is an open access article distributed under the terms of the Creative Commons Attribution License, which permits unrestricted use, distribution, and reproduction in any medium, provided the original author and source are credited.

creativecommons.org/licenses/by/4.0 
Keywords: paleopathology; osteomyelitis; hypertrophic osteopathy; postcrania; infection; Parasuchidae

\section{INTRODUCTION}

Phytosaurs are an extinct clade of archosauriform reptiles whose origins lie either among basal crurotarsan (crocodile-line, or crocodylotarsan) archosaurs (e.g., Benton and Clark, 1988; Sereno, 1991; Juul, 1994; Ezcurra, 2016) or just outside Archosauria (Nesbitt et al., 2011; Stocker et al., 2017). Phytosaur skulls are easily recognized by their elongate snouts (composed primarily of the premaxillae) and their posteriorly retracted, dorsally directed nares. These features in particular give phytosaurs a superficial resemblance to crocodylians, and presumably indicate that the group occupied a similar ecological niche during Late Triassic time. Fossils of phytosaurs are common in Upper Triassic rocks in North America, Europe, North Africa, and India, and less diagnostic materials referable to the group are also known from Thailand, Madagascar, Brazil, and Zimbabwe (e.g., Gregory, 1962; Hungerbühler, 2002; Stocker and Butler, 2013; Barrett et al., 2020). Fossil skulls are particularly common in Germany and the southwestern USA, and these have historically formed the basis for most characters used in phytosaur taxonomy and phylogeny (e.g., Long and Murry, 1995; Hungerbühler, 2002; Stocker, 2010). Although several extensive studies of phytosaurs remain unpublished (Hunt, 1994; Hungerbühler, 1998), recent work on the group has greatly improved phylogenetic resolution (e.g., Stocker, 2012; Kammerer et al., 2016; Jones and Butler, 2018).

Phytosaur fossils, especially their shed teeth, are among the most commonly recovered fossils in many Upper Triassic outcrop belts, yet their postcrania remain relatively understudied, and little is known of their biology beyond their presumed convergence in lifestyle with the geologically younger champsosaurs and crocodylians. Most functional and paleoecological attention has been directed toward the wide array of skull morphologies seen in the group (e.g., Hunt, 1989; Hungerbühler, 1998, 2000, 2002; Lessner and Stocker, 2017). As such, little has been published on their postcrania outside locomotor inferences associated with tarsal structure and the phylogeny of basal archosaurs. Several such studies have utilized the specimen described here (USNM 18313), particularly its ankle (Parrish, 1986a, 1986b; Sereno, 1991; Sullivan, 2010), but none have commented on the pathological nature of many of the other limb elements. In their review of Phytosauria, Stocker and Butler (2013, fig. 4a,e) illustrated the (apparently healthy) right scapulacoracoid and an isolated osteoderm of USNM 18313 as illustrative of "typical" elements of phytosaurs, but did not comment on the pathologies. Indeed, only a few postcranial paleopathologies in phytosaurs have been reported in the literature (e.g., Huene, 1922; Mehl, 1928; Zeigler et al., 2003a; Witzmann et al., 2014). The most substantiated reports are those of Mehl (1928), who reported a broken and healed radius in an indeterminate phytosaur from Wyoming, and Witzmann et al. (2014), who diagnosed spondyloarthropathy in the vertebral column of a German phytosaur first described by Huene (1922). Neither of these pathologies is similar to, or as systemic as, those of USNM 18313. Zeigler et al. (2003a) listed two phytosaur specimens, an ulna and a femur, as pathological, but did not elaborate in the text. As the illustrations in Zeigler et al. (2003a) are inadequate to discern further, these elements remain undiagnosed.

This research describes the multiple pathological elements found as part of USNM 18313, a large, associated skeleton of a phytosaur from Upper Triassic strata near St. Johns in eastern Arizona (Figure 1). We also provide a brief history of study of the region and the specimen, review the locality, stratigraphic context, and age of the specimen (Figure 2), and explicate its taxonomic position and provide a tentative biological interpretation of its pathological state.

USNM 18313 is significant because (1) it is a relatively rare instance of a pre-Jurassic pathological archosauromorph (if this animal suffered from osteomyelitis, as proposed here, it would be the oldest such record in this clade); (2) it is the most extensive postcranial pathology reported for a phytosaur; and (3) it supports arguments on the relative distribution of pathologies on weight-bearing elements in terrestrial versus semi-aquatic archosaurs. Comparison with modern zoological databases shows that confirmed cases of osteomyelitis in the fossil record are roughly congruent with those recorded in modern animals. 


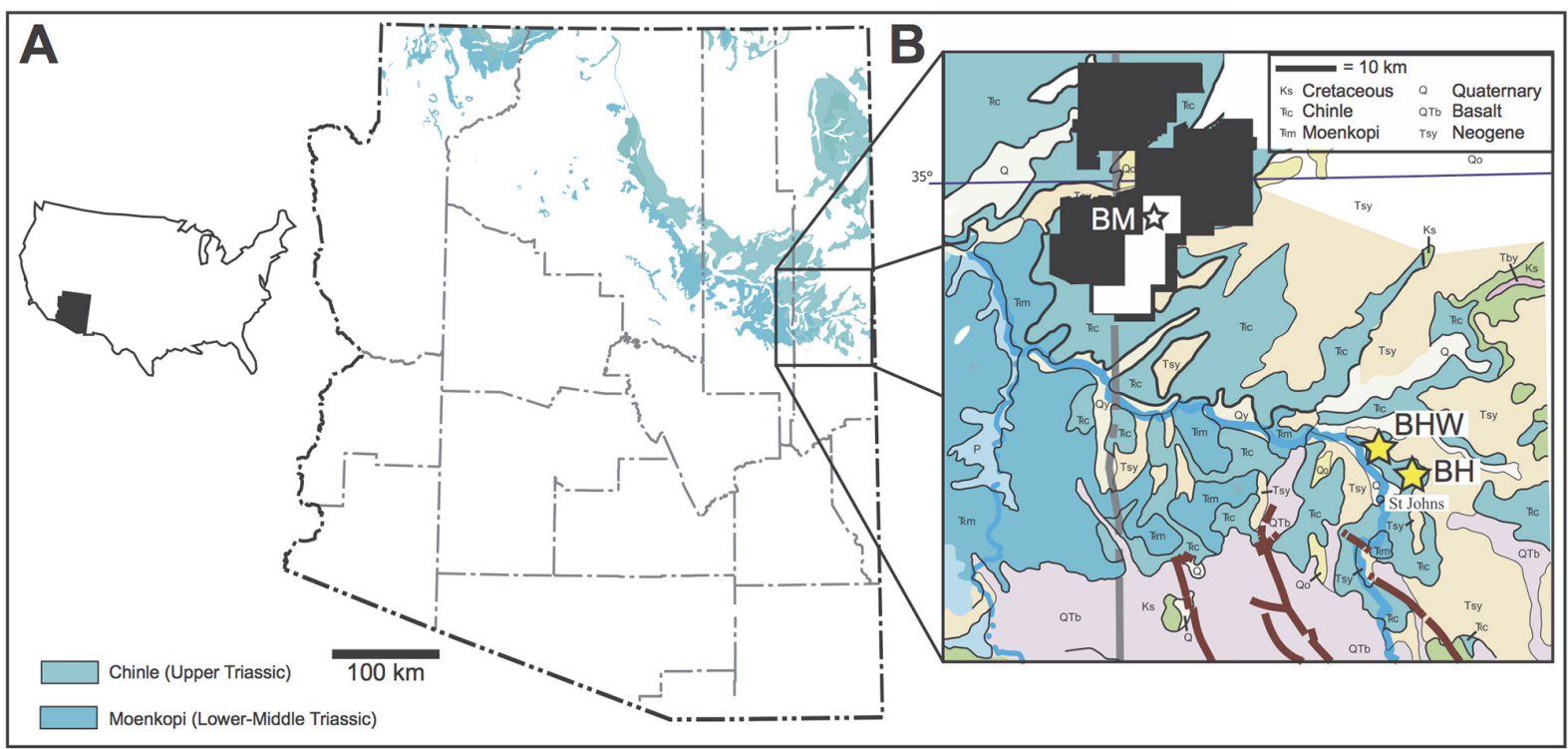

FIGURE 1. Index maps showing the geographic position of the study area in the USA (A) and on a generalized geologic map of east-central Arizona (B) showing the most prolific Triassic localities in east-central Arizona, including the Blue Hills (BH), Big Hollow Wash (BHW) and Blue Mesa (BM) in the Petrified Forest National Park (PFNP). The specimen described here probably came from the Blue Hills but may have come from Big Hollow Wash. The modern administrative boundary of the PFNP is in black, the approximate outline of the smaller monument in 1948 is marked by the white inset. Arizona Maps modified from Richard et al., 2002, Arizona Geological Survey publication DGM-17 (http://data.azgs.az.gov/geologic-map-of-arizona)

\section{Institutional Abbreviations}

$\mathrm{AMNH}=$ American Museum of Natural History, New York, U.S.A.; FMNH = Field Museum of Natural History, Chicago, U.S.A.; MNA = Museum of Northern Arizona, Flagstaff, U.S.A.; MOR = Museum of the Rockies, Bozeman, U.S.A.; $\mathrm{NMMNH}=$ New Mexico Museum of Natural History and Science, Albuquerque, U.S.A.; SMA = Sauriermuseum Aathal, Seegraeben, Switzerland; UCMP = University of California Museum of Paleontology, Berkeley, U.S.A.; USGS = United States Geological Survey; USNM = National Museum of Natural History, Smithsonian Institution, Washington, D.C., U.S.A.

\section{Materials and Methods}

This study focuses on a single pathological phytosaur skeleton, USNM 18313, originally collected for the United States Geological Survey by Guy Hazen in 1948; we provide details of the specimen's provenance and collection in subsequent sections. We analyzed the specimen both manually and digitally, with specimen photographs taken with a Nikon Coolpix® 995 digital camera and subsequently edited in Adobe Photoshop (CS) $®$ and Adobe Illustrator (CS)®. Computer-aided tomography (CT) scans were accomplished in the Smithso- nian's Department of Anthropology, using a Siemans Somotom/Emotion single-slice unit scanner operating at 8-130 keV and 30-240 mA. This process generated $1 \mathrm{~mm}$ thick slices with image size equal to $512 \times 512$. Images were subsequently manipulated using OsiriX 3.0 on a MacIntosh G5.

For thin-sectioning, the specimen was first reinforced and stabilized with EPO-TEK 301 epoxy (manufactured by Epoxy Technology, Inc., Billerica, Massachusetts). Next a working-size block was cut away using a Felker tile saw equipped with a Raytech 6" Red Blazer diamond blade with 0.012"0.015 " kerf. This block was further embedded in a silicone mold with epoxy in a vacuum at $\sim 40$ torr for 5 minutes. After allowing the epoxy to cure for 24 hours at room temperature, the block was removed from the mold, then wet-ground on 320,600 , and 1,200 grit silicon carbide sandpaper successively. After drying, the ground surface of the block was affixed to a standard glass petrographic slide with EPO-TEK 301 epoxy. Following a second 24-hour curing period, the block was cut from the slide, and the specimen on the glass was ground to approximately 20 microns using a Hillquist thin-sectioning machine. The slide was ground to petrographic thickness by hand on a glass plate using 600 and 1,200 grit silicon carbide sandpaper. Final polishing was done with a Leco 


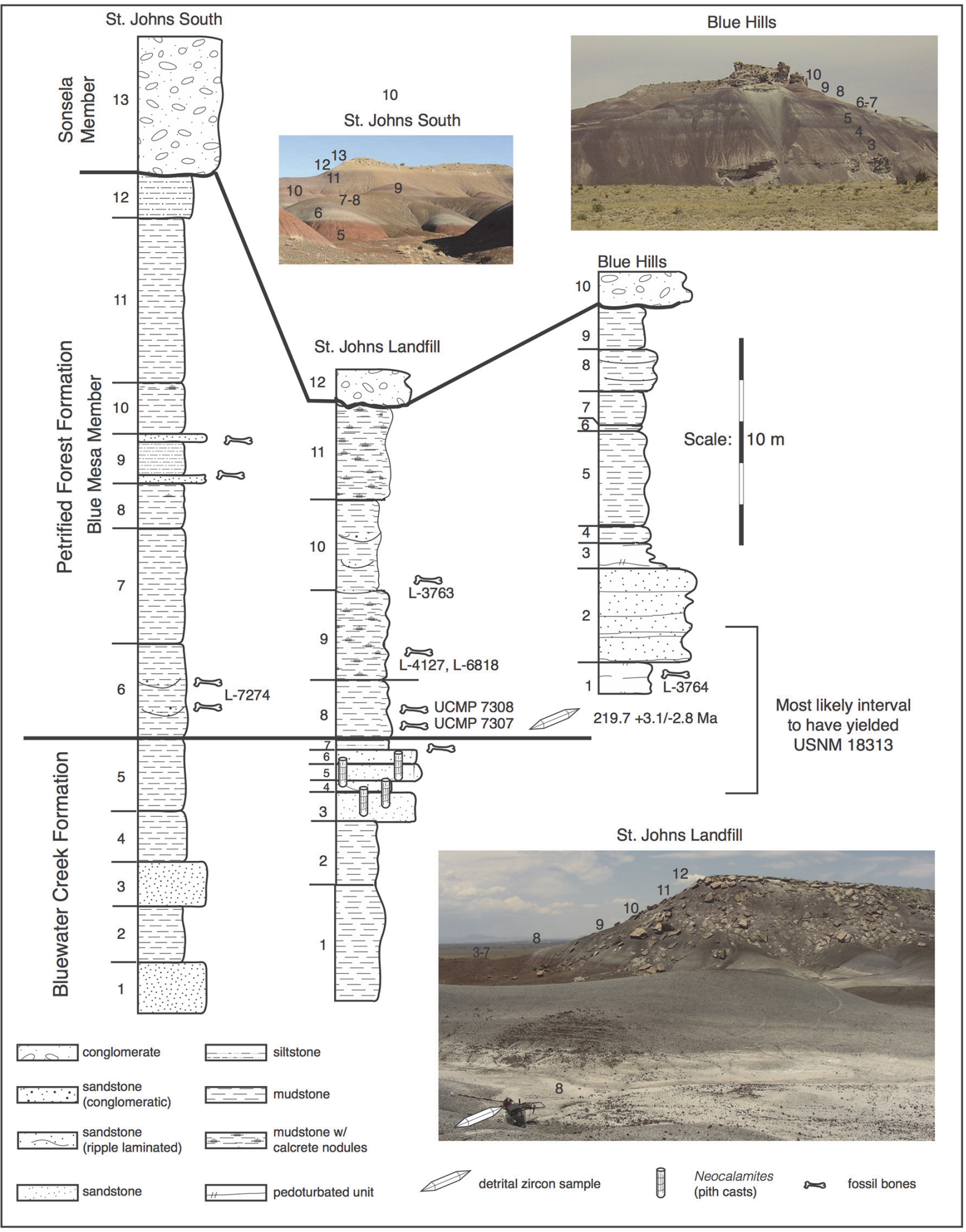

FIGURE 2. Stratigraphy of the lower Chinle in the vicinity of St. Johns, Arizona. Blue Hills and St. Johns Landfill sections from Heckert and Lucas (2003), St. Johns South section is new to this study and described in Appendix 2. 
SS-1000 Spectrum Grinder Polisher, equipped with an 8-inch Buehler Microcloth Polishing Cloth (No. 40-7218) using tin oxide polishing compound.

\section{HISTORY OF STUDY}

The Upper Triassic strata in the vicinity of St. Johns, Arizona, have yielded numerous vertebrate fossils that have been the subject of scientific study since the 1920s, although relatively few collections except those from the Placerias quarry have been thoroughly published (Heckert et al., 2005; see Long and Murry [1995] for a detailed history of twentieth century collectors in Arizona). Charles Camp of the UCMP was the first to make large, systematic collections of vertebrates from this area, including the badlands north and east of St. Johns known locally as the "Blue Hills." The holotype of Machaeroprosopus zunii (Camp, 1930) is one of the few published vertebrates from this area. Later collectors included parties working for the USNM in the 1930s and 1940s and the MNA in the 1970s. The UCMP returned to the Blue Hills in the 1980s, although these collections, like the bulk of Camp's, remain unpublished. Long and Murry (1995) published a generalized faunal list of sites near St. Johns based primarily on the UCMP collections. This list has since been augmented by further collecting as the NMMNH began systematically working localities discovered by Stan Krzyzanowski, including other macro- and microvertebrate sites in the Blue Hills (Heckert and Lucas, 2002a,b, 2003; Heckert, 2002, 2004, 2005; Heckert et al., 2002, 2005). Currently the known tetrapod assemblage of the St. Johns region exclusive of the Placerias quarry is dominated by fossils of metoposaurs, phytosaurs, and other archosauromorphs (Table 1).

\section{Details of Specimen}

USNM 18313 consists of a skull and associated incomplete postcranial skeleton. The skull is extremely large and robust (Figure 3)-1149 mm long from the tip of the snout to the posterior tip of the squamosals and nearly $300 \mathrm{~mm}$ wide at the quadrates. The orbito-dorsal cranial length (ODCL) is $192 \mathrm{~mm}$, which corresponds to a total body size of 5-6 $\mathrm{m}$ in length and $500-800 \mathrm{~kg}$ (Hurlburt et al., 2003). Hazen probably found it lying on its right side, as much of the left side and most of the palate and ventral portion of the braincase are missing. The rest of the left side has been crushed and folded onto the right, and the right side is flared out due to dorsoventral crushing (Figure $3 \mathrm{~A}$ ). The external right side is nearly complete, lacking only the articulation with the lower jaw. The left side is much less complete, preserving a damaged premaxilla and maxilla as well as the nasal, septomaxilla, prefrontal, frontal, postorbital, part of the parietal, and the exoccipital. The preserved axial skeleton consists of nine cervical vertebrae including the axis, six dorsal vertebrae, both sacral vertebrae, a transitional sacro-caudal, 16 caudal vertebrae, and at least 11 ribs as well as numerous fragments of ribs and gastralia (Figure 4). The appendicular skeleton includes the interclavicle, both scapulocoracoids, humeri, ulnae, ischia, femora, tibiae, fibulae, astragali, and calcanea, as well as the left ilium, numerous metapodials, several phalanges, at least two unguals, and many osteoderms and osteoderm fragments.

Guy Hazen excavated this specimen from July through October 1948 while working for the USGS. In a letter to John B. Reeside, Jr. at the Smithsonian (NMNH Department of Paleobiology archives; see Appendix 1), Hazen provided the bulk of the available locality data in a single paragraph (page 2, paragraph 3):

The phytosaur skeleton came from the same horizon as the Club Mosses and Lepodendron [sic] plant material. This horizon continues in all of the Chinle formations which are exposed in the lower section of the Chinle. I traced it around St. Johns and at the northern end of the Petrified National Monument [sic]. This formation appears to have been the channel for a slow moving meandering river. Traces of other reptiles and a lung fish are found throughout the same horizon. (Hazen)

He also stated that "the armor plate kept me from working as rapidly as on a skeleton not having this extra bone material," that "I had to destroy some vertebra [sic], ribs, and armor plate so as to be able to remove portions small enough to handle," and that "[i]f I had cast of these [the ribs] it would've taken much longer." All of these appear to indicate that the specimen was at least closely associated when discovered, if not partially articulated, in addition to being somewhat more complete. His note indicates that the lower jaws were not attached to the skull, and the poor preservation of the left side of the skull and the numerous loose teeth suggest that it was the weathering skull that led to discovery of the site.

Nothing in Hazen's note provides much geographic reference. However, Long and Murry (1995, p. 5) stated that "[i]n late September, 1948, 
TABLE 1. The tetrapod fauna of the St. Johns area exclusive of the Placerias quarry (modified from Heckert et al., 2005).

\begin{tabular}{|c|c|c|}
\hline Stratigraphic Level and Area & Higher Taxa & Species-Level Taxa \\
\hline \multirow{19}{*}{$\begin{array}{l}\text { Uppermost Bluewater Creek } \\
\text { Formation/Blue Mesa Member, } \\
\text { Blue Hills and Picket House Draw }\end{array}$} & Basal Tetrapoda & Buettneria perfecta \\
\hline & & Apachesaurus sp. \\
\hline & Amniota incertae sedis & $\begin{array}{l}\text { Kraterokheirodon colberti } \\
\text { multiple additional taxa }\end{array}$ \\
\hline & Synapsida & Placerias sp. \\
\hline & Archosauromorpha & multiple taxa \\
\hline & Archosauriformes & Type H? teeth* \\
\hline & & Type L teeth* \\
\hline & & Acaenasuchus geoffreyi \\
\hline & & Krzyzanowskisaurus hunti \\
\hline & Phytosauria & Leptosuchus spp. \\
\hline & Aetosauria & Calyptosuchus wellesi \\
\hline & & Desmatosuchus sp. \\
\hline & Suchia & cf. Saurosuchus sp. \\
\hline & & Poposaurus gracilis \\
\hline & Rauisuchidae & Rauisuchidae indet. \\
\hline & Sphenosuchia & Parrishia sp. \\
\hline & & Sphenosuchia indet. \\
\hline & Theropoda & at least one taxon \\
\hline & trace fossils & vertebrate coprolites \\
\hline \multirow{5}{*}{$\begin{array}{l}\text { Lower Chinle Group, Big Hollow } \\
\text { Wash }\end{array}$} & Basal Tetrapoda & Buettneria perfecta \\
\hline & Phytosauria & Smilosuchus sp. \\
\hline & Aetosauria & Calyptosuchus wellesi \\
\hline & & Desmatosuchus haplocerus \\
\hline & Rauisuchidae & "Postosuchus" sp. \\
\hline
\end{tabular}

*microvertebrate morphotypes described by Heckert (2004)

Hazen collected a well-preserved Leptosuchus skeleton (USNM 18313) mixed with several elements of Stagonolepis wellesi at St. Johns." Later (appendix 2, p. 228), these authors specify, without further documentation, the locality as Big Hollow Wash North, and describe USNM 18313 as "much of a postcranium, excellently preserved." It is clear from Hazen's letter (paragraph 4, sentence 4) that the skull and jaws were found with the rest of the skeleton because, in the midst of a description of that skeleton, he observed, "[t]he remains were somewhat disturbed by stream action [in Triassic time] as the jaw was separated from the skull by several feet." Big Hollow Wash is located to the west of St. Johns in the same general outcrop belt that, farther to the east, is known locally as the "Blue Hills" (Figure 1C).
Although none of Hazen's observations pinpoint the locality within currently used stratigraphic units, he is unambiguous about the horizon being within the lower Chinle, sensu Gregory (1917). Based on significantly more detailed local- and regional-stratigraphic studies (e.g., Stewart et al., 1972; Lucas, 1993 and references cited therein), it is clear that the stratum to which Hazen refers, and the strata in the places he mentions, are within the lower Chinle Group (sensu Lucas, 1993; retained as a formation-rank unit by many others). At the time of Hazen's writing, the Petrified Forest was a national monument (i.e., not yet a national park) and considerably smaller than it is now, with its northern boundary located south of the Atchison, Topeka, and Santa Fe railroad/U.S. Route 66 (modern-day Interstate 40) (Figure 1). This land is 
A

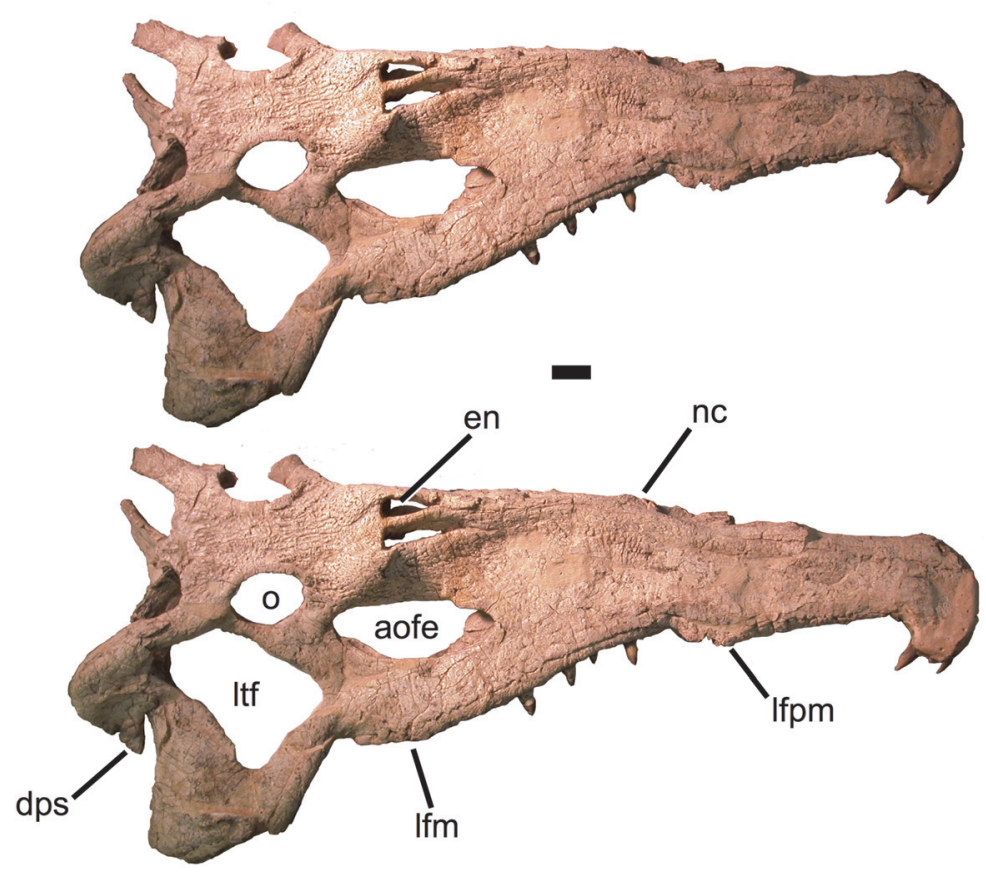

B
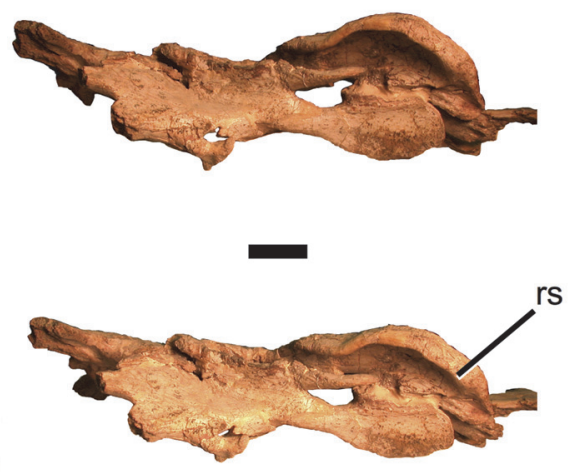
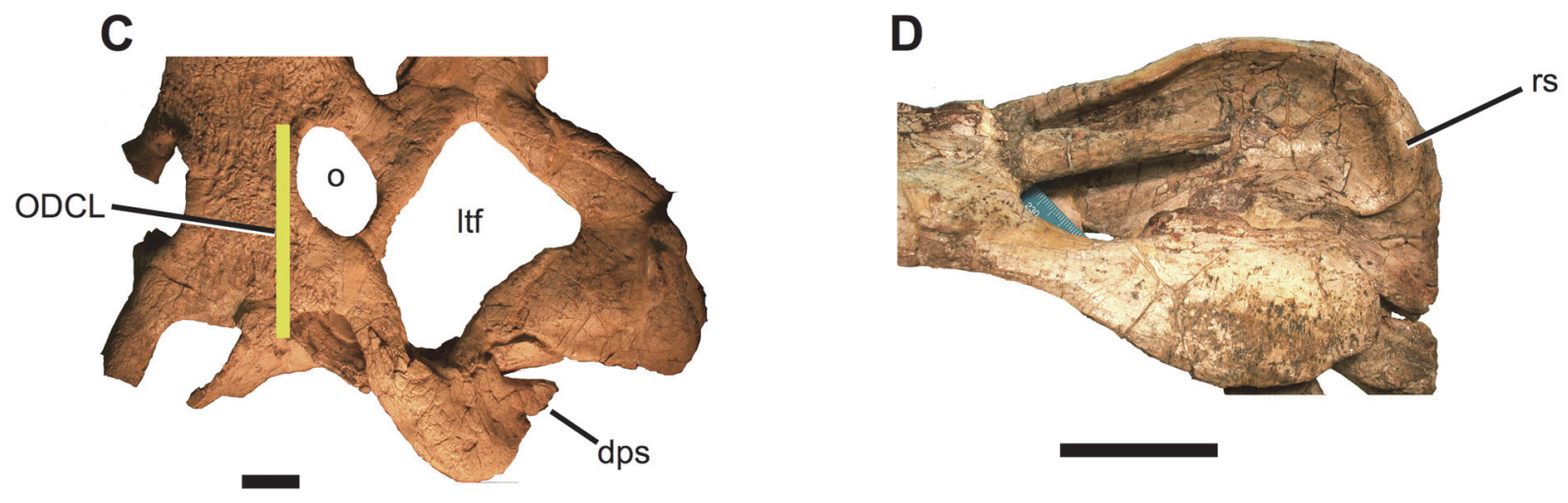

FIGURE 3. Nearly complete skull of USNM 18313 showing taxonomically relevant morphological details. (A) Stereopair of nearly complete skull in right dorsolateral view. (B) Stereopair of skull in posterior view. (C) Posterior portion of skull in dorsal view, with yellow line indicating ODCL. (D) Close-up of right squamosal region in posterior view. Abbeviations: aofe = antorbital fenestra; en = external naris; dps = descending process of squamosal; ltf = lateral temporal fenestra; Ifm = lateral flare of maxilla; Ifpm = lateral flare of premaxilla; $\mathrm{nc}=$ narial crest; ODCL = orbito-dorsal cranial length (after Hurlburt et al., 2003); o = orbit; rs = ridge on squamosal. Scale bars equal $5 \mathrm{~cm}$.

underlain by the strata of the lower Chinle Group, principally the Blue Mesa Member of the Petrified Forest Formation; by contrast, the area north of there (which was added later) includes the vast majority of younger strata in the present-day park. Lungfishes are not biostratigraphically significant in the Chinle, but their fossils tend to derive from either the Bluewater Creek Formation low in the group or the Painted Desert Member of the Petrified Forest Formation significantly higher stratigraphically (e.g., Murry, 1989; Heckert and Lucas,
2006; Milner et al., 2006). In addition, their fossils are readily found in the lower Chinle in the Blue Hills northeast of St. Johns (ABH personal obs.). The horsetail ("Club Moss") Neocalamites is not biostratigraphically significant either (e.g., Ash, 1987), but occurs in abundance in the upper Bluewater Creek Formation in the Blue Hills and is most typically recovered from the lower Chinle Group generally (ABH pers. obs.).

Many institutions have collected in the Blue Hills, and the stratigraphy there is accessible and 


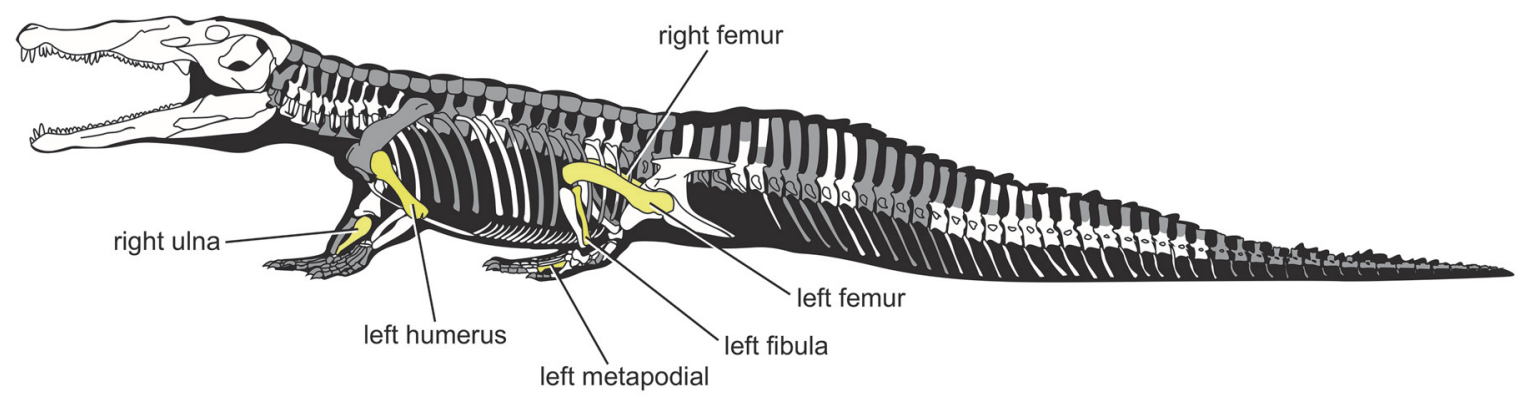

FIGURE 4. Reconstruction of the skeleton of USNM 18313 in left lateral view. Preserved bones are in white, bones that were not preserved are in gray, and pathological elements are in yellow.

well-studied (Heckert and Lucas, 2003; Heckert et al., 2005; Figure 2, Appendix 2). Big Hollow Wash is less well-known, but the southernmost stratigraphic section we document here (Figure 2) shows that the units present in the Blue Hills, and the fossiliferous interval high in the Bluewater Creek Formation and low in the Blue Mesa Member, are present and persistent south of the primary collecting areas in the Blue Hills. Thus we consider it likely that this is the stratigraphic interval from which Hazen collected the phytosaur specimen described herein.

\section{Associated Fauna}

A small minority of the elements included with USNM 18313 do not pertain to a phytosaur. These include two small temnospondyl centra and several aetosaur osteoderms. The centra are small $(\sim 1 \mathrm{~cm}$ maximum dimension), with ovoid faces, but approximately equant in width and height and slightly less long. These characteristics suggest that they pertain to a juvenile metoposaur, presumably Anaschisma (=Buettneria, Koskinonodon) because the coeval Apachesaurus has centra that are longer than tall (Hunt, 1993). The external surfaces of both centra are extensively pitted, suggesting that they may have been gut contents subjected to attack by stomach acid and/or digestive enzymes. The aetosaur is represented by a dorsal paramedian osteoderm that is at least twice (but less than four times) as wide as long, possesses a discrete anterior bar, a robust boss emanating from the posterior margin of the osteoderm, and a radial pattern of pits, grooves, and ridges that emanates from the boss. These are characteristics of the aetosaur Calyptosuchus (= Stagonolepis) wellesi (Long and Ballew, 1985; Long and Murry, 1995; Heckert and Lucas, 2000; Parker, 2007, 2018). Given the size and completeness of this element, it is much less likely that it is a gut content, and presumably represents another fossil from the same locality. Calyptosuchus wellesi is an index taxon of the Adamanian Land Vertebrate Faunachron (= LVF; Heckert and Lucas, 2000; Hunt et al., 2005; Lucas et al., 2007) and is also a common fossil in both the Bluewater Creek Formation and the Blue Mesa Member of the Petrified Forest Formation in Arizona (e.g., Long and Murry, 1995; Heckert et al., 2005; Parker, 2007, 2018). Finally, there is also at least one small archosauriform (possibly phytosaur) cervical vertebra, a probable aetosaur ventral osteoderm, and a few small, nondiagnostic elements included in USNM 18313 that do not pertain to the large, pathological skeleton.

\section{STRATIGRAPHY AND AGE}

Three members of two formations can be mapped in the immediate vicinity of the Blue Hills and east of St. Johns (although the statewide geologic map lumps all together as "Upper Triassic Chinle") (Figure 1). These stratigraphic units are the lower, "red-bed"-dominated upper member of the Bluewater Creek Formation and the overlying Petrified Forest Formation, which can be subdivided into the lower, mudstone-dominated Blue Mesa Member and the coarser-grained Sonsela Member (Heckert and Lucas, 2003). To date, all vertebrate fossils from the Blue Hills have been recovered from localities either high in the Bluewater Creek Formation (a few localities) or low in the Blue Mesa Member (the majority of the localities) (Heckert et al., 2005), although Marsh et al. (2019) have recently reinterpreted the "Blue Mesa Member" outcrops here and in western New Mexico as part of the basal Sonsela. Regardless of which unit, the age-diagnostic component of the assem- 
blage includes the phytosaur Smilosuchus (= Leptosuchus; tentatively referred to $S$. adamanensis), the aetosaur Calyptosuchus (=Stagonolepis) wellesi, and the possible revueltosaur Krzyzanowskisaurus hunti (Long and Murry, 1995; Heckert et al., 2005; Heckert and Miller-Camp, 2013; Stocker and Butler, 2013), all of which indicate an Adamanian (St. Johnsian) age sensu Hunt et al. (2005) (Table 1). Tying the nonmarine tetrapod record to the marine Standard Global Chronostratigraphic Scale (SGCS, "marine time scale") is difficult, but the Adamanian generally and the St. Johnsian in particular were traditionally considered latest Carnian in age (Hunt et al., 2005; Lucas et al., 2007), although subsequent authors have accepted the "long Norian" correlations set forth by Furin et al. (2006) and reassigned much of the lower Chinle to the early Norian. Consequently, recent estimates of the Adamanian are that it represents early/earliest mid-Norian time (e.g., Parker and Martz, 2011; Martz and Parker, 2017). Indeed, Smilosuchus is one of the taxa that defines the Adamanian teilzone (biozone) of Martz and Parker (2017). Thus, given the available geographic and stratigraphic information, we suggest that USNM 18313 almost certainly was recovered from the lower Chinle Group, probably the Blue Mesa Member of the Petrified Forest Formation, and thus is of Adamanian (St. Johnsian) age (Figure 2). Regionally persistent beds of reworked volcanic material at the base of the Blue Mesa Member as traditionally interpreted ( $=$ base of the Sonsela of Marsh et al. [2019]) yield a maximum depositional age of approximately 217-218 Ma (Heckert et al., 2009; Irmis et al., 2011; Marsh et al., 2019; Rasmussen et al., 2021), which is middle Norian on current versions of the SGCS.

Other data associated with USNM 18313 support the age assignments provided here, in spite of the paucity of detailed locality data. Although the bones are well prepared, there is some residual matrix adhering to them, including in some of the lesions on the pathological elements. This matrix includes light greenish-gray bentonitic mudstone and grayish white lithic-rich sandstone, lithologies typical of the Blue Mesa Member. These sediments are also consistent with Hazen's use of the term "lower Chinle" in his letter. Also, the white bones are more typical of Blue Mesa Member preservation in the Blue Hills; Bluewater Creek Formation bones from this area tend to have a reddish cast (ABH personal obs.).

\section{TAXONOMY AND SYSTEMATICS}

The taxonomic assignment of USNM 18313 has fluctuated since its discovery. As it has never served as the type specimen of any phytosaur species, its identification has rested on the ability to refer it to an existing taxon. Most authors who have discussed USNM 18313 have not mentioned the skull at all, which is puzzling given its large size and good condition. We suspect that this apparent oversight is because the skull was on display in the USNM for more than 30 years, during which time it was not identified by specimen number in the exhibition. The postcranium was kept in the collections, but there was little to indicate that it pertained to the same individual as the exhibit skull. For this reason, we suspect that most authors (at least in recent decades) have studied only the postcranium, or at best had a long-distance view of the skull, and that has contributed to the difficulties assigning USNM 18313 to a known taxon. Furthermore, many phytosaur taxa have not been studied in detail in recent years and are not diagnosed by autapomorphies; even fewer include any postcranial features in their diagnosis.

The only species-level assignment of USNM 18313 (e.g., Stocker and Butler, 2013; Jones and Butler, 2018) has been to Smilosuchus gregorii (Camp, 1930), with that species originally having been assigned to Machaeroprosopus (Camp, 1930) and variously transferred to the genera Phytosaurus (Gregory, 1962), Nicrosaurus (Westphal, 1976), Rutiodon (Ballew, 1989), Smilosuchus (Long and Murry, 1995; Stocker and Butler, 2013), and Leptosuchus (Irmis, 2005), although in several other cases (Parrish, 1993; Padian et al., 2009; Stocker, 2010) there has been no accompanying diagnosis of that species. The type specimen of $S$. gregorii is UCMP 27200, a skull with an associated partial postcranial skeleton (Camp, 1930). Camp's (1930:43) original diagnosis included a mixture of unique and shared features, which were described only in comparison with other species he assigned to Machaeroprosopus. Many of these features were repeated by Colbert (1947:60), who referred a second well-preserved skull from correlative strata in north-central Arizona (AMNH FARB 3060) to this taxon. The skull of USNM 18313 is extremely similar to that of UCMP 27200 , which is even larger (see Camp, 1930, pl. 6) and was recovered from correlative strata in northeastern Arizona (Heckert et al., 2005). It also shows a strong resemblance to AMNH FARB 3060.

Three studies have listed autapomorphies for the species gregorii, but unfortunately none 
referred USNM 18313 to that taxon. Ballew (1989) listed six autapomorphies of 'Rutiodon' gregorii but did not mention USNM 18313 at all. Long and Murry (1995) used eight features to define the species, which they made the type of the new genus Smilosuchus, but identified USNM 18313 as Leptosuchus sp. (which they diagnosed by seven autapomorphies). Two more recent papers (Irmis et al., 2007; Sullivan, 2010) also identified the present specimen as Leptosuchus sp. Despite the inconsistencies among these identifications, they agree in placing this specimen as an intermediate-grade phytosaur among taxa traditionally classified as "rutiodontines." Kammerer et al. (2016) included two species of Smilosuchus, S. lithodendrorum, and $S$. gregorii, in their phylogenetic analysis but made no diagnosis of either taxon. Most recently, Jones and Butler (2018) diagnosed Smilosuchus gregorii based on a unique combination of two characters, referring USNM 18313 to this taxon.

Although few phylogenetic studies have mentioned USNM 18313, the specimen is sufficiently well preserved to permit an assessment of its phylogenetic position using published characters. Historically, most workers have used one or more of the following: Ballew (1989), Long and Murry (1995), and Hungerbühler (2002). An additional, unpublished scheme (Hunt, 1994) expands on Ballew's (1989), and other authors have provided additional insight and commentary (e.g., Doyle and Sues, 1995). In more recent years, a series of new, detailed studies have greatly increased phylogenetic resolution within the clade (Stocker, 2010, 2012; Jones and Butler, 2018).

These studies generally agree on the following hypotheses: (1) all but the most primitive phytosaurs possess external nares that are dorsal, but not anterior, to the antorbital fenestra; (2) more derived phytosaurs have supratemporal fenestrae that are increasingly depressed below the skull roof and proportionately narrower and more slitlike; (3) the size and shape of the squamosals are taxonomically informative; and (4) overall skull proportions delineate relatively robust and gracile taxa that may otherwise be indistinguishable according to hypotheses 1-3 (but see Stocker, 2010). To date, no serious attempt to utilize phytosaur postcrania (or even lower jaws) for taxonomic purposes has been published since Camp (1930).

The most important taxonomic features of USNM 18313 are the placement of the nares relative to the antorbital fenestrae (Figure 3A); the size, shape, and position of the supratemporal fenestrae (Figure 3C-D); the size and shape of the squamos- als (Figure 3); and the size and shape of the snout (Figure 3A). The nares are retracted to lie dorsal and medial to the antorbital fenestrae, the derived condition in phytosaurs (Hunt, 1994; Long and Murry, 1995; Hungerbühler, 2002; Stocker, 2010). The supratemporal fenestrae, however, are large, round, and open at the level of the skull roof anteriorly, but slightly depressed posteriorly, which is usually considered an intermediate condition (Rutiodon + Pseudopalatus node of Ballew, 1989; Rutiodontinae of Long and Murry, 1995; character 32:1 of Stocker, 2010) (Figure 3C-D).

Hungerbühler (2002) explicitly used the squamosal in five of 47 characters and Stocker (2010) expanded this to nine of 43 . Both rely on the squamosal at least peripherally in other characters, especially those relating to the supratemporal fenestra, rendering it the most phylogenetically informative bone in the phytosaur skull. The squamosals of USNM 18313 are robust, with triangular descending processes that point ventrally when seen in lateral view (Figure 3A). In dorsal view, they extend somewhat posteriorly but are not elongate or rod-like (Figure 3C). Medially the squamosals possess a faint ridge that runs anteroposteriorly dorsal to the articulation with the exoccipital (Figure 3D). This combination of features is again diagnostic of intermediate-grade phytosaurs (Rutiodon sensu Ballew, 1989; Rutiodontinae sensu Long and Murry, 1995; Hungerbühler, 2002). Stocker (2010) considered the "dorsoventrally expanded, posteriorly rounded posterior processes of the squamosals" diagnostic of Smilosuchus + "Leptosuchus" adamanensis (Stocker, 2010:fig. 11, node 10 ), and a similar character was used by Jones and Butler (2018) to partly diagnose S. gregorii.

The snout of USNM 18313 exhibits two potentially important features (Figure 3A): (1) a prominent crest extends anteriorly from the nares and (2) in dorsal view the tooth row "flares" laterally twice. Dimorphism has been documented in feature (1) in Pseudopalatus (Zeigler et al. 2002, 2003b; this genus is generally considered synonymous with Machaeroprosopus in more recent studies, e.g., Jones and Butler, 2018). We cannot discern sutures that would indicate whether the crest of USNM 18313 includes substantial contributions from the septomaxillae (as in "Pseudopalatus"), but the condition observed here is consistent with that of presumed male phytosaurs according to Zeigler et al. (2002, 2003b). It is also consistent with the "full rostral crest" described as part of the diagnosis of S. gregorii (Jones and Butler, 2018). The two flared regions of the snout-once in the posterior 


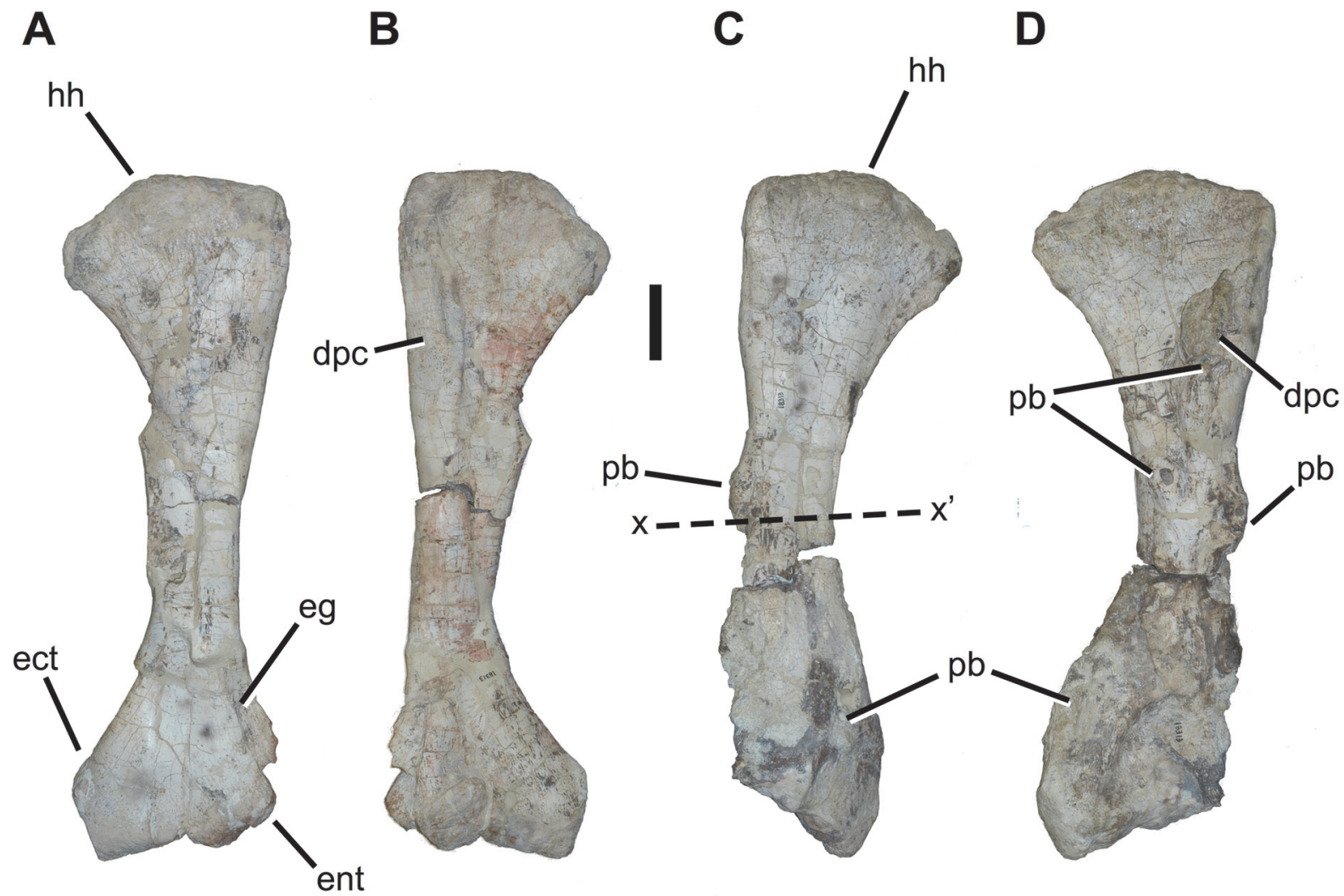

FIGURE 5. Right (A, B) and incomplete left (C, D) humeri of USNM 18313 in dorsal/lateral (A, C) and ventral/medial $(B, D)$ views. Abbreviations: ect = ectepicondyle; eg = entepicondylar groove; ent = entepicondyle; $h \mathrm{~h}=$ humeral head; $\mathrm{pb}=$ pathological bone; $\mathrm{x}-\mathrm{x}^{\prime}=$ location of histological thin-section shown in Figure 5 . Scale bar equals $5 \mathrm{~cm}$.

portion of the premaxilla and again in the posterior maxilla-constitutes the "brachyrostral" condition (Hunt, 1989) and are historically considered a key characteristic of robust phytosaur taxa (e.g., Ballew, 1989; Hunt, 1989, 1994; Long and Murry, 1995). Indeed, not only is the snout massive, but the back of the skull is relatively wide and robust, with a particularly robust quadratojugal and quadrate (Figure $3 \mathrm{~A}, \mathrm{C}$ ).

The skull morphology of USNM 18313 is consistent with "R." gregorii according to the schemes of Ballew (1989) and Hunt (1994), Rutiodontinae sensu Long and Murry (1995), and the node including S. gregorii and "L." adamanensis of Stocker (2010). Based on these observations, the most recent phylogenetic topology available (Jones and Butler, 2018), and the strong general similarities between UCMP 27200, AMNH FARB 3060, and USNM 18313, we agree with these latter authors in assigning the latter specimen to Smilosuchus gregorii.

\section{DESCRIPTION}

Phytosaur postcrania are not especially well studied, in part because they are seldom associated with the more diagnostic skulls. Indeed, Case (1930) is one of very few authors to ascribe any taxonomic significance to postcranial variation in phytosaurs, and so far no one has attempted to distinguish phytosaur taxa by the elements that are pathological in USNM 18313, namely the left humerus, right ulna, both femora, left and, possibly, right fibula, and at least two metapodials (Figure 4). Even recent phylogenetic analyses (e.g., Stocker, 2010, 2012; Jones and Butler, 2018) rely almost exclusively on cranial characters. In the following sections we describe typical phytosaurian elements and then provide detailed descriptions of their pathological counterparts in USNM 18313.

\section{Humerus}

The right humerus exhibits anatomy typical for phytosaurs (Figure 5A). It is moderately elongate, approximately three times as long as the anteroposterior width of the proximal head. In dorsolat- 


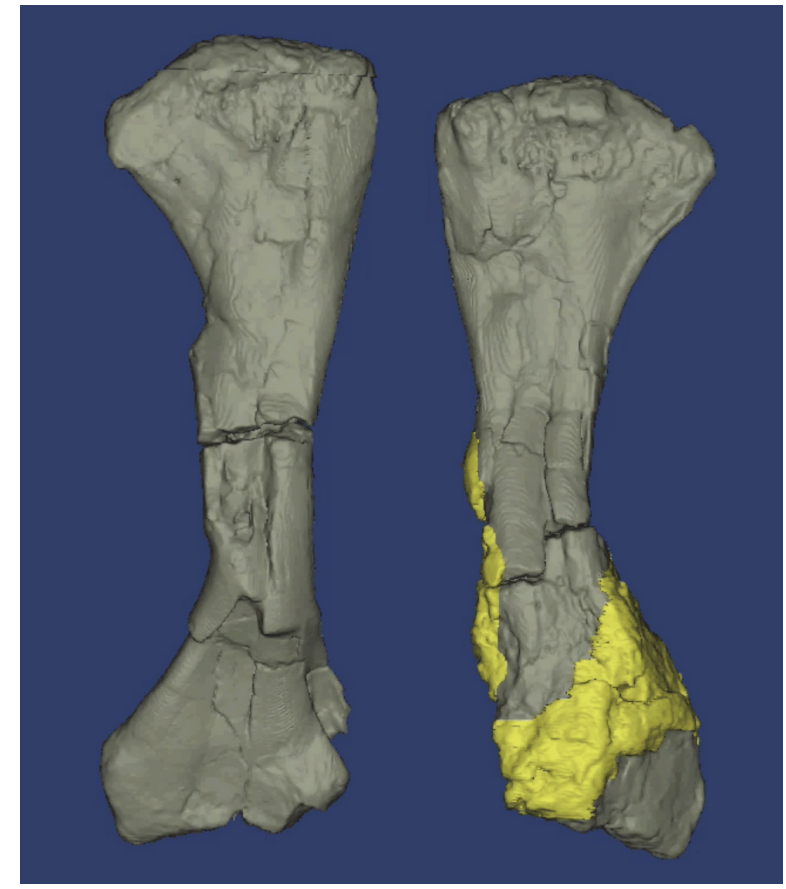

FIGURE 6. Movie showing rendered CT-scan of humeri of USNM 18313. Pathological bone on the left humerus is highlighted in yellow. Movie available for download at https://palaeo-electronica.org/content/2021/3385-pathological-phytosaur.

eral view, the anterior margin is generally straight except for a projection surrounding the entepicondylar groove, and the posterior margin is concave. The head is convex proximally and expanded posteriorly. A prominent, but not exceptionally long or large, deltopectoral crest is situated as a short ridge on the medial (ventral) surface, starting at a point proximal to the most distal extent of the head. The shaft narrows through the midshaft before expanding again posteriorly to a similar extent as the proximal end. The distal end bears a robust entepicondyle and similarly large ectepicondyle, the latter occupying much of the posterior portion of the distal end. With the exception of the articular surfaces of the proximal and distal ends, and to a lesser degree the deltopectoral crest, the bone surface is smooth.

The left humerus of USNM 18313 is striking in exhibiting several obviously pathological lesions that considerably alter the typically smooth medial surface (Figures 5D, 6). Several of these lesions have completely engulfed the deltopectoral crest and surrounded the midshaft, greatly increasing its cross-sectional dimensions. In pathological terms, the deltopectoral crest (deltoid tuberosity) is irregular with exostoses and cavitations obscuring normal architecture. There are two cavitations on the concave face. One is approximately $180 \mathrm{~mm}$ from the proximal end and is $10 \times 7 \mathrm{~mm}$. Bony exostoses are ramped or sloped at the periphery and extend $6-12 \mathrm{~mm}$ from the edges of the cavity. An exophytic lesion begins at the [medial] edge at the level of the distal edge of the first lesion. The cavity here has irregular, sharper, and ill-defined borders and may be preservationally distorted. The exophytic bone is slightly irregular at the crest of the nodule and smoother near the periphery of the lesion. Substrate still attached to the distal portion of the humerus inhibits full evaluation of pathological lesions in this area. The affected left humerus is $425 \mathrm{~mm}$ long, while the unaffected right element is $435 \mathrm{~mm}$ long.

In order to best understand these pathologies, we had a thin section made of the pathological left humerus (Figure 7), as this element was both incomplete (with a preservationally damaged distal end) and one of the most severely afflicted elements (with the possible exception of the right femur). Because the other lesions appear macroscopically similar, we suspect that the observations documented here are typical of those on the other affected elements. Unfortunately, there has been little histological work on phytosaur limbs previously, with published sections limited to two femora from Arizona sampled by de Ricqles et al. (2003, pl. 1) and another from Austria by Butler et al. (2019, fig. 16).

As seen in thin-section (Figure 7), the outermost dimensions of the relatively normal cortex are $55 \times 25 \mathrm{~mm}$; the cortex itself is $9-10 \mathrm{~mm}$ thick. The medullary cavity is filled with trabecular bone (Figure $7 \mathrm{C}$ ) and reduced in size, probably due to taphonomic changes: there is a focus of indentation and fracture on the lateral aspect of the bone (Figure 7A-B). The cortex is discontinuous along the anteromedial aspect of the bone and replaced by woven bone with regular, though often interrupted morphology. This periosteal new bone overlaps the normal cortex at both the anterior and caudomedial extents of the cortical defect (Figure 7D) and is up to $13 \mathrm{~mm}$ thick (Figure 7A-B). The exophytic bone is arrayed roughly perpendicular to the existing cortical surface. In some areas, lakes of new woven bone trabeculae abut separate lakes of trabeculae that are acutely arranged in a different direction (Figure 7D). Near the center of the broad area of periosteal new bone formation is a cavitation that overlies one of these interrupted lakes. Multifocal taphonomic changes often obscure the relationship between the normal bone and exostoses, and also within the pathologic alter- 

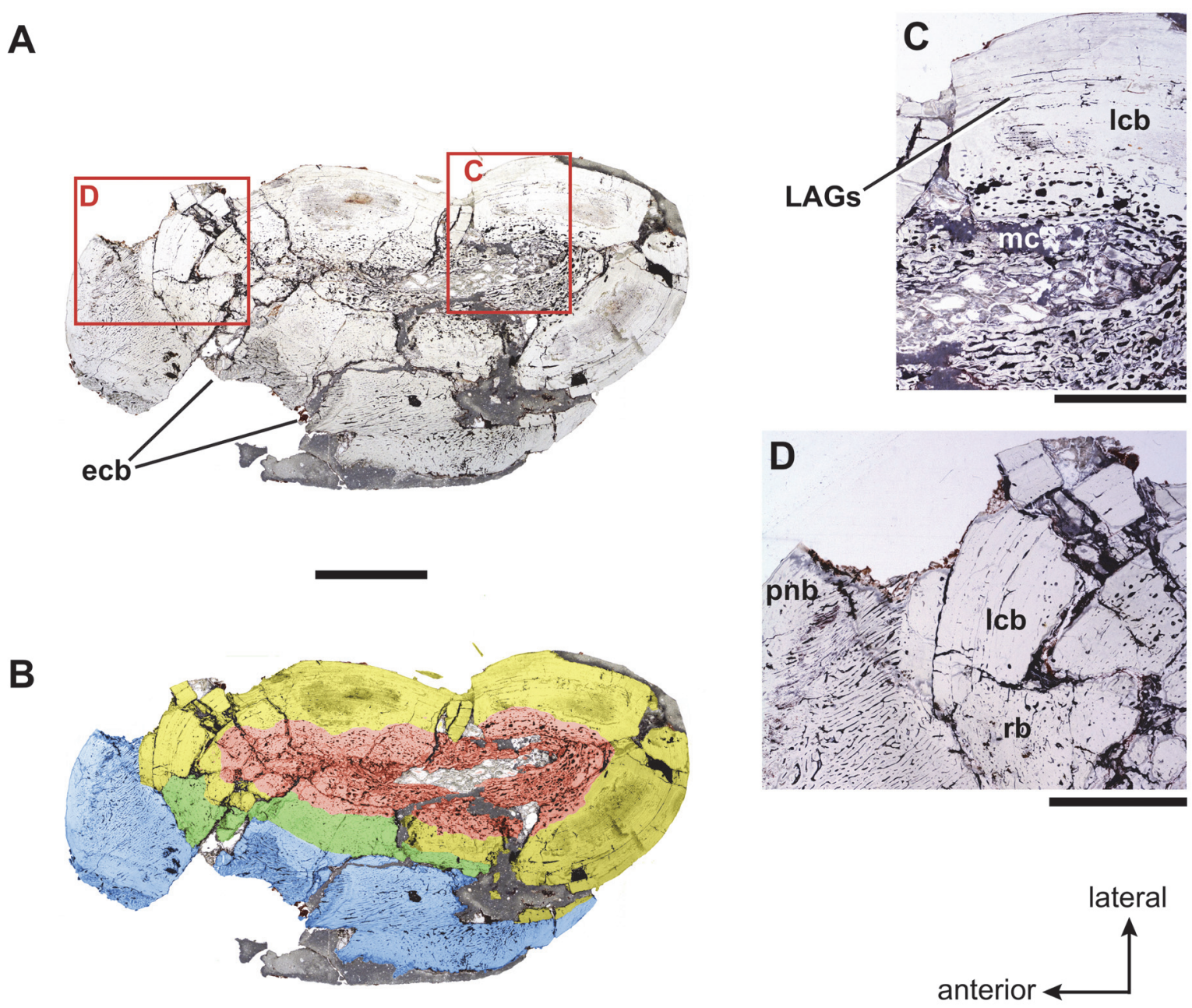

FIGURE 7. Histological section of left humerus of USNM 18313 in distal view (A-B) Overview of complete section showing regions highlighted in C-D, with color-added version (B) to highlight different tissues. (C) Normal lamellar cortical bone (top) transitions into the woven bone of the medullary cavity (bottom); (D) Periosteal new bone formation composed of woven bone arranged nearly perpendicularly to the eroded lamellar cortical surface; fragments of normal cortical bone and remodeled bone are taphonomically juxtaposed. Abbreviations: ecb = eroded cortical bone; LAGs = lines of arrested growth; lcb = lamellar cortical bone; mc, medullary cavity; pnb = new periosteal bone (pathological); rb $=$ remodeled bone. Colors: red $=$ spongy bone of medullary region; yellow = lamellar cortical bone; blue, periosteal new bone (pathological); green = remodeled bone (pathological). Scale bars equal $1 \mathrm{~cm}(a-b)$ and $5 \mathrm{~mm}(\mathrm{c}-\mathrm{d})$.

ation itself. In the more pristine (unaffected) regions of the bone several LAGs (lines of arrested growth) are visible as discontinuities within the lamellar bone.

\section{Ulna}

The left ulna of USNM 18313 is relatively typical for a phytosaur (Figure 8A-B). The more robust proximal end is concave along the anterior surface between the radial articulation and the end of the substantial olecranon process. It is convex around the remainder of the proximal end and its posterior surface. The olecranon itself is rugose and globular, with a broadly rounded outline in mediolateral view, and is expanded slightly relative to the adjacent bone surfaces. By contrast, the radial articulation is quite small and takes the form of a truncated cone. The shaft is markedly straight in both anteroposterior and mediolateral views, tapers gently distally, and expands slightly at the distal end. In cross-section the shaft is "D"-shaped, with a convex lateral surface and a flat medial surface, against which the radius would have been 
A

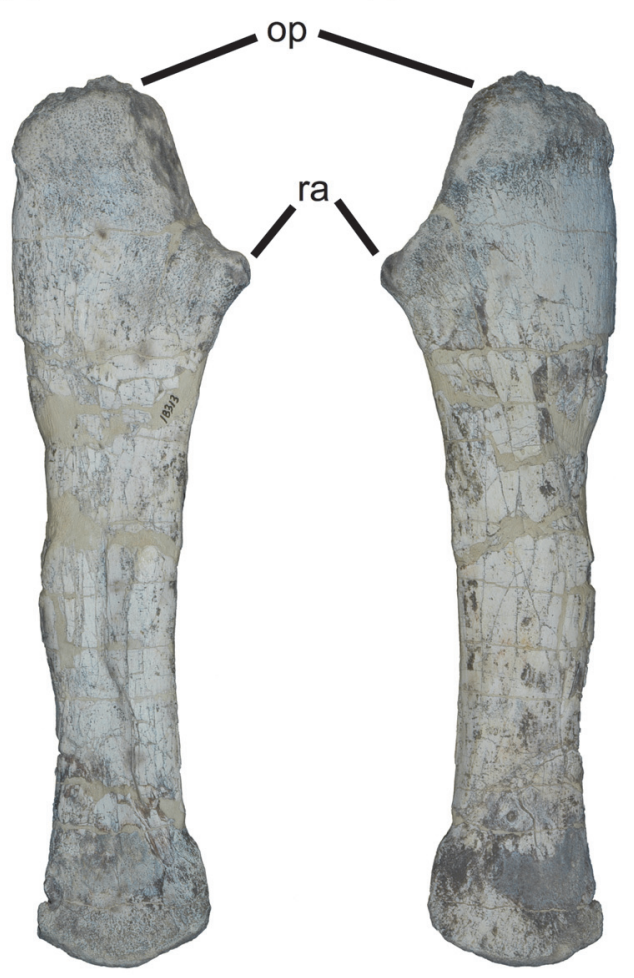

C

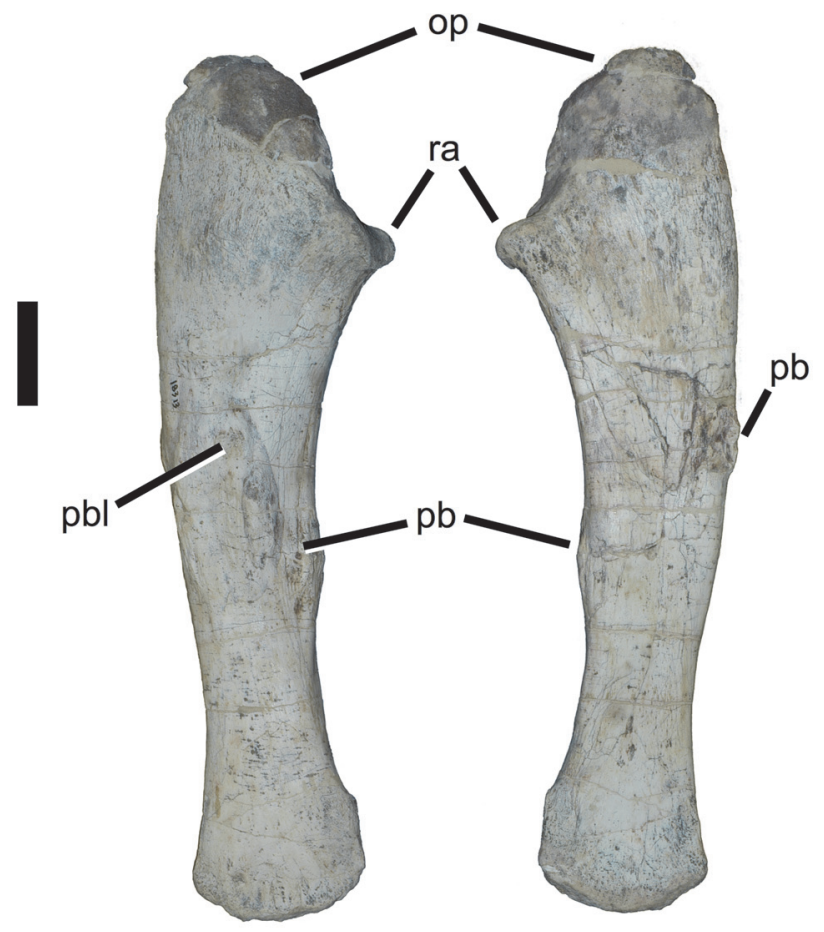

FIGURE 8. Left (A, B) and right (C, D) ulnae of USNM 18313 in medial (A, D) and lateral (B, C) views. Abbreviations: op = olecranon process; $p b=$ pathological bone; $\mathrm{pbl}=$ pathological bone lesion; $\mathrm{ra}=$ radial articulation. Scale bar equals $5 \mathrm{~cm}$.

appressed. The distal end is thicker mediolaterally than the adjacent shaft.

Only the right ulna shows macroscopic evidence of pathology (Figures 8C-D, 9). An irregular band of bone that is $40-88 \mathrm{~mm}$ wide traverses the lateral midshaft surface. Within this band are numerous longitudinal ridges and furrows, some of which bear evidence of lesion formation. The exophytic bone wraps slightly onto the medial surface as well. Interestingly, although the articular ends seem unaffected, the entire shaft appears more broadly curved than the left ulna. This pathologic ulna is $325 \mathrm{~mm}$ long, while the unaffected left element is $345 \mathrm{~mm}$ long.

\section{Femur}

Phytosaur femora are, like the humeri, relatively elongate (proximodistal length approximately four or more times proximal width). Although both femora of USNM 18313 are pathologic (Figure 10), the left is substantially less so, and we describe its general anatomy first. In dorsoventral view (Figure 10A-B), the element is sigmoidal, with an anteriorly projecting head and a pair of posteriorly directed distal condyles. The greater trochanter occupies most of the anteriorly broadened proximal end, forming a flat, anterodorsally facing surface. The head is convex and compressed dorsoventrally, tapering to an acuminate tip. Along the proximal one-third to one-half of the bone, the fourth trochanter forms an obvious, but not especially robust, linear ridge along the middle of the ventral surface. The narrowest diameter occurs about two-thirds down the shaft, which then expands slightly and twists to reach the distal condyles. This is also the point where the majority of the pathological bone occurs on this specimen, consisting primarily of exophytic lesions with ramped or sloped margins (Figure 10A-B). Only the proximal and distal articular surfaces and the area surrounding the fourth trochanter bear any rugose texture, otherwise the external surface is smooth.

The right femur has experienced extensive alteration through both remodeling and development of exophytic lesions (Figures 10C-D, 11). The greater trochanter is much reduced, especially in comparison to the left, and does not project as 


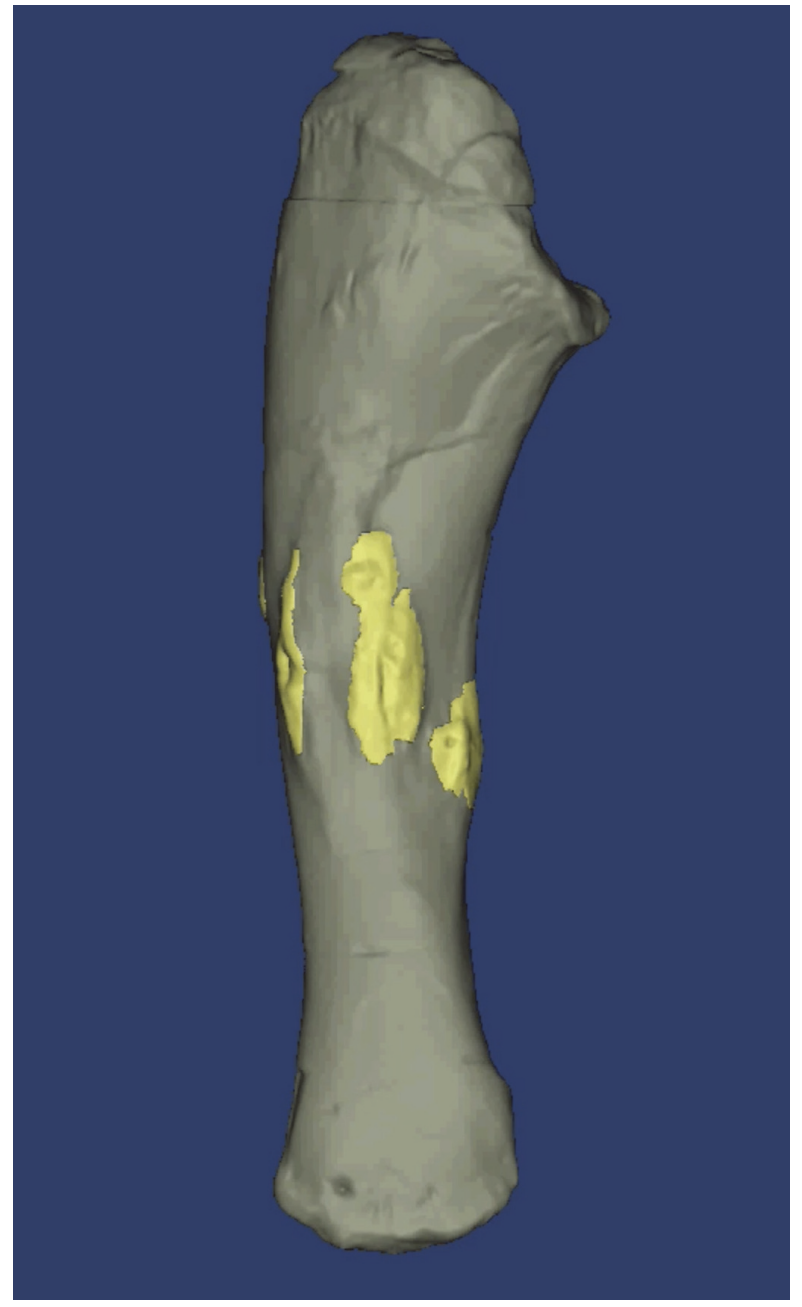

FIGURE 9. Movie showing rendered CT-scan of right ulna of USNM 18313. Pathological bone is highlighted in yellow. Movie available for download at https:// palaeo-electronica.org/content/2021/3385-pathologicalphytosaur.

far anteriorly as it normally does in a phytosaur. Found in isolation this element would be difficult to recognize as phytosaurian. In pathological terms the femoral lesions on the right femur include an exophytic lesion that extends distally from a point on the fourth trochanter that is approximately 110 $\mathrm{mm}$ from the head. It is sharply defined at the proximal border and projects up to $11 \mathrm{~mm}$ off the surface. This lesion was fractured post-fossilization 14 $\mathrm{mm}$ from the proximal border, but continues $13 \mathrm{~mm}$ down the shaft of the bone with a less well-defined border that extends approximately 1-2 $\mathrm{mm}$ off the bone surface. Several confluent, exophytic plates extend the bony reaction along the metaphysis. The largest of these plates is $39 \times 54 \mathrm{~mm}$, with a thickness ranging up to $9 \mathrm{~mm}$. On the medial edge of the bone is a cavitated lesion ca. $10 \mathrm{~mm}$ deep and $12 \times 17 \mathrm{~mm}$ across. This cavitation is surrounded by proliferative bone that is raised above the surface at its border and blends with the bone surface within $26 \mathrm{~mm}$ (Codman's triangle). Approximately $180 \mathrm{~mm}$ from the distal end of the bone is another lesion with at least three cavities ranging from $6 \times 9 \mathrm{~mm}$ to $3.5 \mathrm{~mm}$ in diameter. Similar ramping bony proliferation surrounds this lesion and extends up to $31 \mathrm{~mm}$ proximally.

In addition to the rampant exophytic bone growth documented here, the femora also show extensive remodeling and destruction of the "normal" architecture. Comparison of the two elements shows a substantial loss of symmetry, which is particularly evident in the proximal head of the right femur, where the greater trochanter is abbreviated (Figure 10). The markedly osteopathic right femur is $510 \mathrm{~mm}$ long, while the less affected left femur is $500 \mathrm{~mm}$ long.

\section{Fibula}

In USNM 18313 the essentially complete left fibula is clearly pathological (Figure 12). The fibula of a typical phytosaur is a gracile, relatively unspecialized element. The proximal and distal ends are slightly expanded mediolaterally but significantly so anteroposteriorly, with the distal end larger than the proximal end. The proximal end is relatively flat except for a protuberance in the anterior half of the articular surface; it overhangs the shaft slightly medially where it contacted the tibia, producing a weak embayment. The posterior end is markedly canted such that the anterior side extends much farther distally than the posterior side. A slight upturn bevels the anteriormost side of the distal end. The iliofibularis process forms a prominent, oblique ridge on the lateral and posterolateral surfaces of the shaft. The shaft itself tapers evenly from either end toward the midshaft, but is otherwise straight in anteroposterior view and weakly sigmoidal in mediolateral view. It bears an elliptical cross-section except for flattened portions of the medial surface where it contacts the tibia both proximally and distally (Long and Murry, 1995, fig. 53).

The left fibula of USNM 18313 is exceptionally gracile and strongly mediolaterally compressed (Figure 12). The proximal half bears extensive pathological modification consisting of cavitated exophytic lesions covering much of the medial and lateral surfaces. Approximately $75 \mathrm{~mm}$ from the distal end of the fibula on the anteromedial surface is a $20 \times 14 \mathrm{~mm}$ crateriform exostosis, which projects up to $11 \mathrm{~mm}$ off the surface of the cortical 

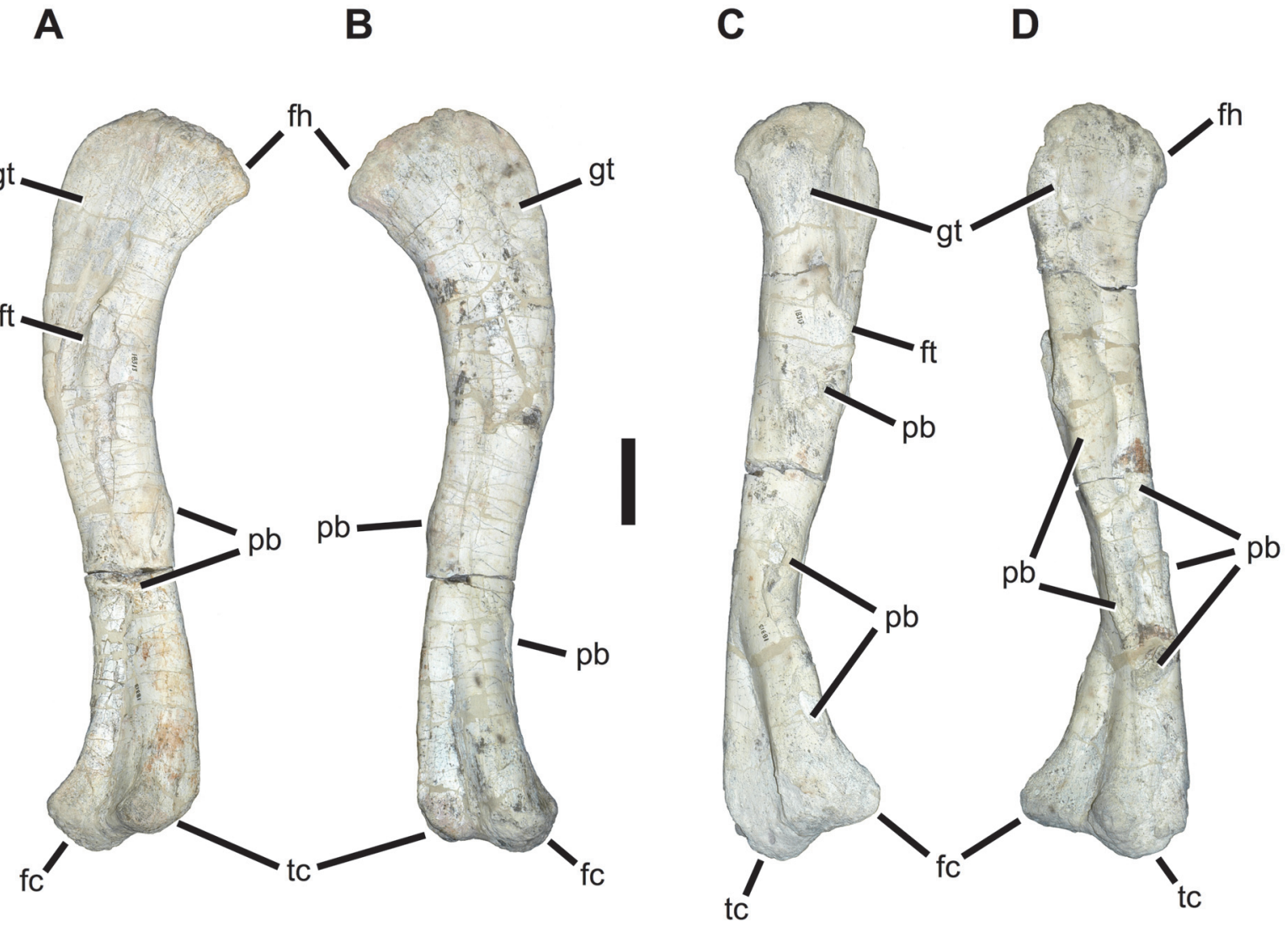

FIGURE 10. Left (A, B) and right (C, D) femora of USNM 18313 in ventral $(A, C)$ and dorsal $(B, D)$ views. Note that the right femur is distorted such that $(C)$ is closer to anteroventral. Note that the right femur is distorted such that $(C)$ is closer to posterolateral. Abbreviations: $\mathrm{fc}=$ fibular distal condyle; $\mathrm{fh}=$ femoral head; $\mathrm{ft}=$ fourth trochanter; $\mathrm{gt}=\mathrm{greater}$ trochanter; $\mathrm{pb}=$ pathological bone; tc $=$ tibial distal condyle. Scale bar equals $5 \mathrm{~cm}$.

bone. Opposite this lesion is a similar $62 \times 24 \mathrm{~mm}$ exophytic lesion. The extreme rugosity of the iliofibularis process may be pathologically exaggerated as well.

Another element may represent the proximal end of the right fibula (Figure 13A). It displays a sizable area of pathological bone growth in a position similar to that of the left, on the lateral surface proximal to the iliofibularis process.

\section{Metapodials}

Phytosaur metapodials are poorly studied and, aside from the distinctive archosaurian 'hooked' fifth metatarsal, difficult to assign to a more specific anatomical position with confidence. Relatively few metapodials are preserved with USNM 1831, but at least one left element is pathological (Figure 13B). Based on the specimen's overall size (preserved length more than $120 \mathrm{~mm}$ ), it is probably a metatarsal. Approximately $49 \mathrm{~mm}$ from its proximal end is a ramped, crateriform exostosis that is $23 \times 13.7 \mathrm{~mm}$. A second, unidentified metapodial element also exhibits pathological bone growth (Figure 13C).

\section{CLINICAL DIAGNOSIS AND INTERPRETATION}

At least eight bony elements of USNM 18313 exhibit one or more areas of periosteal new bone formation (exostoses). The distribution of these lesions is limited to the limbs and spares the axial skeleton, including the skull and lower jaws. Exostoses appear to be largely composed of woven bone extending from the surface of the lamellar, cortical bone. Speaking broadly, pathologic bone modification may have traumatic, neoplastic, metabolic, nutritional, or infectious/inflammatory etiologies (Thompson, 2007). Although the pathology exhibited by this phytosaur is inconsistent with some of these etiologies, it partially reflects changes characteristic of others. Each of these 


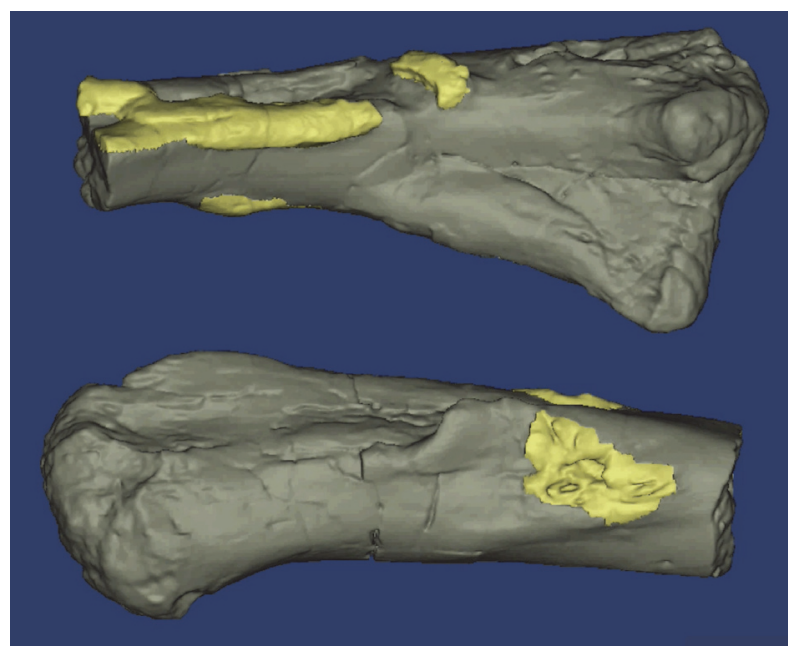

FIGURE 11. Movie showing rendered CT-scan of distal (top) and proximal (bottom) halves of right femur of USNM 18313. Pathological bone is highlighted in yellow. Movie available for download at https://palaeo-electronica.org/content/2021/3385-pathological-phytosaur. processes will be explored herein with regard to our observations of USNM 18313.

Trauma is the most common cause of bone pathology in modern dogs and cats (Johnson et al., 1994). A bone will break when the elastic capacity of the matrix is overcome by a force; the subsequent pattern of fracture is dictated by the type of force (e.g., point, broad), the load on the bone (compression vs. distraction), and the presence of rotational forces along the axis. Complete fractures of bone result in circumferential separation of the fracture ends (or less frequently, longitudinal separation; Porta, 2005) and may divide the bone into two or more segments. Focal, traumatic perforation of bone cortex is uncommon. Perforation of the skull may occur with high velocity impacts, such as gunshot injury to extant animals. High-pressure point forces from carnivoran canine teeth or raptor talons can cause perforation of the skull of mammals or birds, or the thin cortex of avian long bones (TCV pers. obs.), but the stouter long bones of ter-
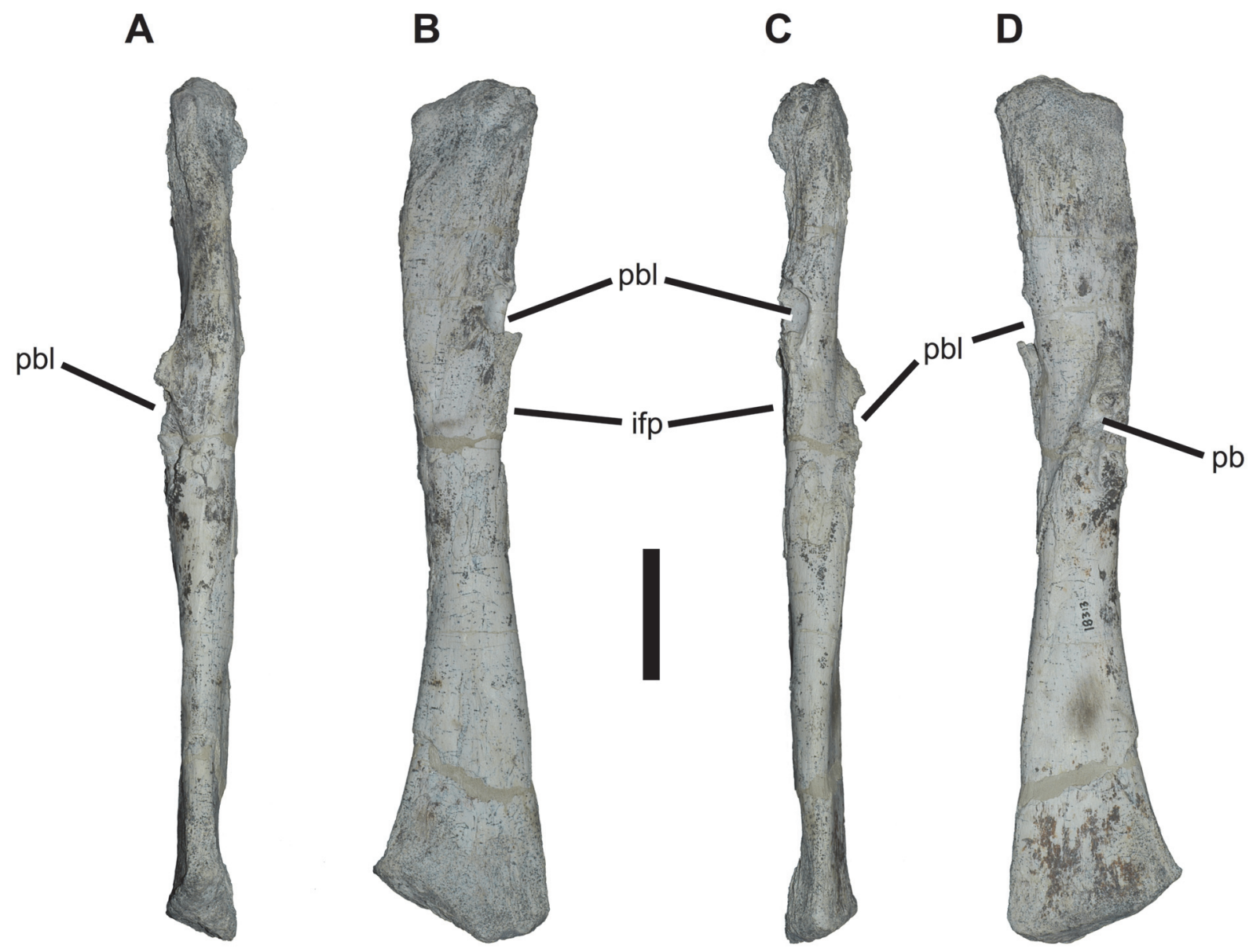

FIGURE 12. Left fibula of USNM 18313 in anterior (A), lateral (B), posterior (C), and medial (D) views. Abbreviations: ifp = iliofibularis process; $\mathrm{pb}=$ pathological bone; $\mathrm{pbl}=$ pathological bone lesion. Scale bar equals $5 \mathrm{~cm}$. 
A

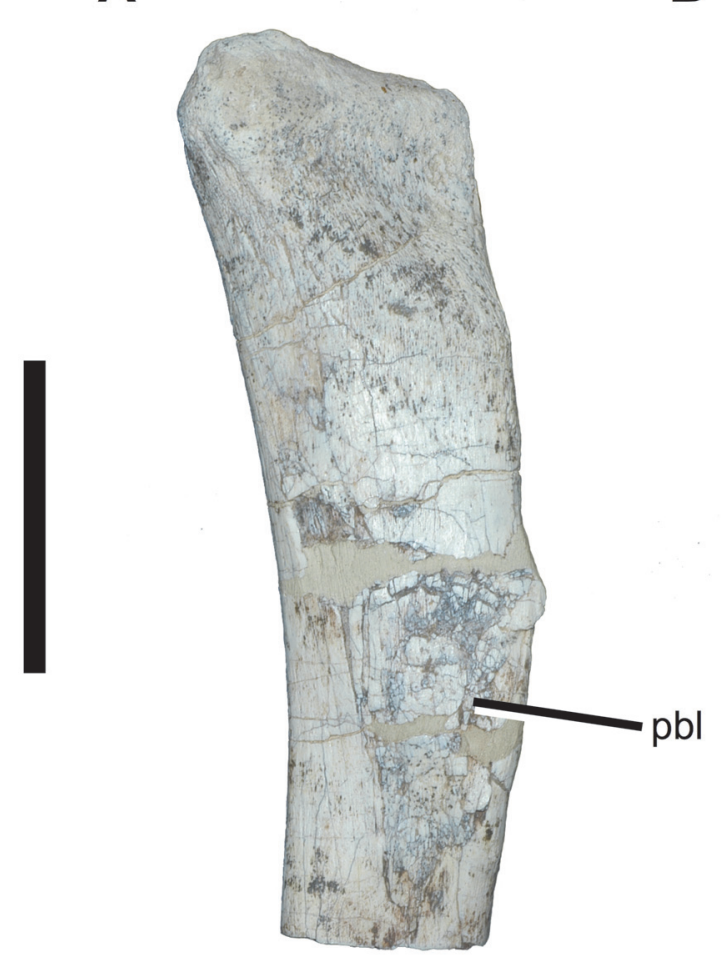

B

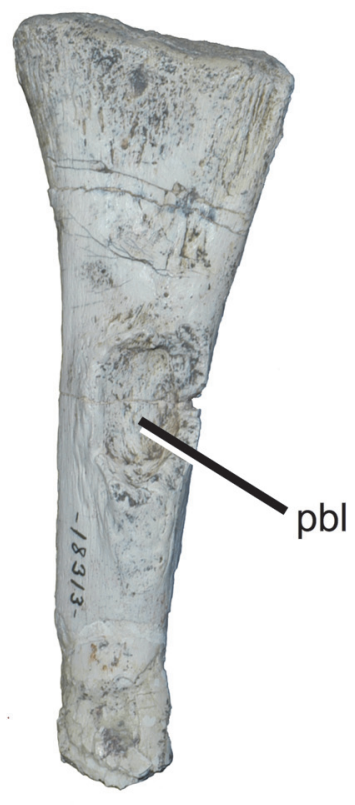

C

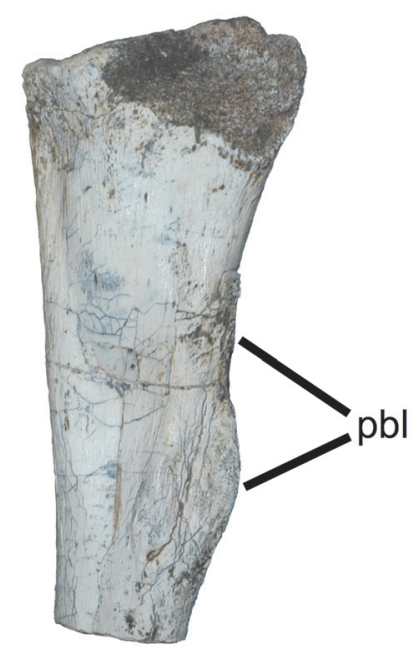

FIGURE 13. Additional pathological elements of USNM 18313. (A) Probable right fibula, proximal end in lateral view. (B) Left metapodial. (C) Metapodial. Abbreviation: pbl = pathological bone lesion. Scale bar equals $5 \mathrm{~cm}$.

restrial animals will completely fracture in response to such forces. Intra- and interspecific aggression resulting in bone pathology is almost always associated with significant overlying soft tissue damage, such as lacerations of the muscles and/or skin (Intarapanich et al., 2017). Bite-associated bone pathology has been documented in other extinct reptiles (Lingham-Soliar, 2004; Xing et al., 2018), though the lesions are few and not as widespread as in USNM 18313.

The process of fracture healing involves an initial soft tissue response, followed by proliferation of bony matrix at the fracture site. Depending on the level of natural (or medically induced) stabilization between the fractured ends, active remodeling of the bone will result in a bony callus that fully follows the fracture lines and binds the fractured ends together in as little as three weeks (Irwin and Ferguson, 1986). After initial stabilization, the reactive, woven bone that was initially produced to bridge the defect is resorbed and replaced by compact, lamellar bone. Bone segments that are permitted to move against each other during the remodeling phase of healing may result in a larger callus, delayed healing, or non-union of the fractured ends. Bone perforations follow the same healing process, wherein the callus manifests as a thickened area of bone that may either surround the defect or fill in the hole caused by the point force. Given enough time and proper alignment, fractured bones can re-attain their prior, unmolested morphology. In extant reptiles, the complete healing process may take up to 18 months (Mader, 2014).

Although the bone remodeling documented here is extensive, there is no evidence of complete, circumferential fracture, or focal puncture (bite wound) in any of the affected elements of USNM 18313 , either on the bone surfaces or in the radiological analyses. Theoretically, an armor-bearing carnivore such as a phytosaur would be better protected from bites than would theropod dinosaurs, which are the fossil group with the most extensively documented occurrences of skeletal traumarelated pathologies associated with bites (e.g., Tanke and Currie, 2000; Molnar, 2001; Tanke and Rothschild, 2002; Rothschild and Tanke, 2005, but note that some reinterpretation may be warranted in light of Wolff et al., 2009; Hone and Tanke, 2015). We have not observed any evidence of similar pathologies in the preserved dermal armor, but 
most of the remaining specimens are paramedian osteoderms that were arranged in two columns dorsal to the vertebral series, not over the limbs, which were generally covered with much smaller osteoderms (Camp, 1930). The widespread distribution of bone pathology in USNM 18313 makes a single traumatic event less likely. The soft tissue damage associated with a single aggressionrelated or other trauma that affected at least eight elements would almost certainly not have been survivable. The presence of extensive bone remodeling to heal the defects in the cortex requires longer-term survival, indicating that the inciting etiology must have occurred at least 2-3 weeks prior to death. In animals with a slower metabolism, the time required to develop lesions such as these may be prolonged. Additionally, all of the preserved lesions include woven bone that was not fully remodeled or healed (e.g., Figure 7), indicative of lesions that developed over no more than a few months. Knowing that many osteoderms were sacrificed to collect the remainder of the skeleton, it is impossible either to demonstrate or to rule out bite-related injuries as root causes for the pathology documented here. However, we emphasize that there is no direct evidence for such a cause.

Neoplasia is the unregulated growth of cells stemming locally from a specific tissue and can be expressed in multiple ways. A neoplastic growth begins with a mutation within a single cell that is subsequently propagated as that cell divides and replicates in an uncontrolled manner (Wang et al., 2019). The growth may invade its native tissue and/or infiltrate neighboring organs. Malignant tumor cells may travel via the bloodstream to distant organs, most commonly the lungs and liver. Neoplasia is rarely reported in extant, wild, vertebrate populations (Ewald and Swain Ewald, 2015). This apparent rarity may be an artifact of the limited lifespan of wild animals versus those in captivity (thus avoiding diseases associated with senescence) as well as the low relative frequency of post-mortem examination for animals that die in the wild. To our knowledge, no reports exist of primary bone tumors in wild, extant reptiles. For this reason, although this etiology is possible for USNM 18313, we consider it extremely unlikely.

Osteosarcoma, a neoplasm originating in osteoblasts, usually begins as a solitary mass. Metastases often form in distant soft tissues, especially those of the lung (Thompson, 2007), but manifestation of tumors in multiple bones is rare (Hoenerhoff et al., 2004). Microscopically, neoplastic osteoblasts form a disorganized, variably miner- alized matrix that effaces and expands normal bone architecture. Osteosarcoma is extremely rare in the saurian paleopathological record, but has been reported recently in both a stem-turtle (Haridy et al., 2019) and the Cretaceous dinosaur Centrosaurus (Ekhtiari et al., 2020). When neoplastic osteoblasts produce ossified matrix, the distribution is haphazard and unstructured, unlike the regular, perpendicular orientation of woven bone against the intact cortex of USNM 18313 (Figure 7 ). The histomorphology and the multifocal distribution of the lesions of USNM 18313 are inconsistent with a diagnosis of osteosarcoma.

Osteochondromatosis is a benign neoplastic condition that results in multiple, concurrent, bony and cartilaginous proliferations on the bones of young humans and some domestic species (Thompson, 2007). It is hereditary and not the result of a single-cell mutation. Histologically, the marrow cavities of the existing bone are contiguous with multi-nodular pathologic outgrowths composed of both cartilage and osteoid matrix. This is in contrast to the lesions of USNM 18313, which appear to be composed almost entirely of bone and extended outward from the periosteum without involving the marrow cavity (Figure 7).

Hypertrophic osteopathy $(\mathrm{HO})$ is a metabolic condition reported in humans, domestic dogs, and an iguana (Barten, 2000). HO may be idiopathic or precipitated by intrathoracic inflammatory conditions or neoplasia and resolves upon removal of the inciting cause. Without treatment of the underlying etiology, the disease is progressive and invariably fatal. Lesions of $\mathrm{HO}$ spare the axial skeleton and consist of periosteal new bone formation along the metaphyses while sparing the joints. The exostoses are generally bilaterally symmetrical and of consistent thickness around the metaphysis of the long bones or metacarpals/tarsals (Olson and Carlson, 2017). New woven bone in HO is generally arranged at right angles to the surface of the cortex. Although the distribution of $\mathrm{HO}$ lesions in the appendicular skeleton is similar to the location of lesions in USNM 18313, the distribution within each bone is not perfectly reflective of that in $\mathrm{HO}$, whereas all four limbs of this phytosaur were affected, the lesions on the bones were unevenly distributed within and between the affected bones and lack symmetry. Also, $\mathrm{HO}$ lesions encompass most of the diaphysis to a relatively consistent thickness, whereas the lesions in USNM 18313 were largely nodular or crateriform (Figure 7). Similarly, the perpendicular arrangement of woven bone against the lamellar cortex is consistent 
between $\mathrm{HO}$ and USNM 18313. In sum, the confinement of lesions to the axial skeleton and the organization of woven bone perpendicular to the core support a diagnosis of $\mathrm{HO}$, but the asymmetrical, nodular to crateriform lesions are inconsistent with that diagnosis.

A number of infectious agents have been associated with pathologic changes in bone. Osteomyelitis is inflammation of the bone and is most commonly caused by a bacterial infection, but mycotic or viral agents have also been associated. Bacterial osteomyelitis is generally established via hematogenous (blood-borne) dissemination and accompanies septicemia. Local soft-tissue injury or trauma that damages the periosteum may also lead to bacterial invasion into the adjacent damaged bone surface. Osteomyelitis, while frequently diagnosed in paleopathological specimens, is not extensively documented in extant reptiles. In the modern literature, various bacterial organisms have been associated with inflammation of the spine in an iguana and several species of snake (Ramsay et al, 2002, Brown et al, 2006), and in the forelimb of a dwarf crocodile (Heard et al, 1988). Rare reports describe capture of wild, seemingly healthy animals that subsequently developed bony lesions in their new, artificial environment (Jacobson, 2007). "Mouth rot" or tooth root infections have resulted in mandibular or maxillary osteomyelitis in modern crocodiles and lizards (Munevar et al., 2019; TCV, unpub. data). Osteomyelitis caused by the blood-borne spread of bacteria in reptiles often manifests in the spinal column (Mader, 2014). There is a comprehensive description of osteomyelitic lesions in an Early Cretaceous basal ornithopod with multiple other lesions (Gross et al., 1993; Hanna, 2000). Bony changes in this animal were largely associated with trauma, but draining tracts, indicating infection, were present in the digits and rib. Hanna (2000) hypothesized that large carnivores may live longer with their injuries, due to predation avoidance, and thus allow time for bones to react to injurious or infectious insults.

The response of bone to destruction and stimuli from infectious and inflammatory sources is multifaceted. Osteoclasts and osteoblasts are mobilized to remodel and stabilize the damaged tissue. The result is a proliferation of bone primarily from the periosteal surface, but also from the endosteal surface. This new bone formation elevates the periosteum from the surface of the bone, with the greatest distance between the two layers found close to the focus of the bony insult. Radiographically, this is represented as Codman's triangle and is characteristic of osteomyelitis or bony neoplasia (Thompson, 2007) and reminiscent of many lesions seen in USNM 18313 (Figures 5-13). Below, we explore several pathogens affecting the bones of extant animals we consider relevant to the pathological features expressed on USNM 18313.

Some bacterial species, such as Staphylococcus aureus, are osteotropic and attach to bone surface proteins such as sialoproteins and collagen, and also invade osteoblasts (Josse et al., 2015). The bacteria incite the production of inflammatory mediators as well as destroy the osteoblasts, ultimately resulting in bone loss. From their intracellular location, they can inhibit the bony proliferation that normally accompanies inflammation. The lesions in USNM 18313 were proliferative rather than lytic and, thus, not consistent with $S$. aureus infection.

Salmonella has been well documented as an agent of spinal osteoarthritis in snakes (Ramsay et al., 2002; Grupka et al., 2006, Bemis et al., 2007). This bacterium leaves the circulation in the highly vascular cartilaginous end plates and releases destructive substances such as hyaluronidase. Subsequent inflammation and release of toxic metabolites from heterophils further erodes the articular cartilage and subjacent bone leading to fulminant osteomyelitis. The erosive effects of Salmonella infection, and tropism for joints, are unlike the pathological bone in USNM 18313, which is largely additional (although there has been extensive remodeling of the femora). Additionally, though extant reptiles often manifest bacterial osteomyelitis in the vertebral column, none of the vertebrae of USNM 18313-which include representatives of the cervical, dorsal, sacral, and caudal series-were affected. The axial skeleton was not completely recovered (Figure 4), however, so the possibility that some of the missing elements were pathological cannot be excluded.

Mycobacterium has a tendency to localize to the medullary cavity of bones, inciting a granulomatous inflammatory response. This response has been well documented in tree kangaroos (Dendrolagus sp.), in which there appears to be a unique predisposition to infection with this organism (Mann et al., 1982; Montali et al., 1998), as well as a more anecdotal report in a Pliocene macropod (Rothschild et al., 1997a). This pathogen is also suggested to be the cause of focal vertebral pathology in a sauropod dinosaur (Garcia et al., 2017). We rule out Mycobacterium because the lesions in 
USNM 18313 do not appear to involve the medullary cavity (e.g., Figure 7).

Infection of muscle with Hepatozoon americanum in dogs is associated with extensive periosteal new bone formation (Thompson, 2007). The limbs are most often affected, though lesions can be found on the pelvis and spine. Like $\mathrm{HO}$, the distribution of lesions is often symmetrical, and the exophytic woven bone extends nearly perpendicularly from the cortical surface. Different species of Hepatozoon have been found in modern reptiles, including Caiman (Viana and Marques, 2005), but no skeletal lesions have been documented in association with the disease. Of the pathogens discussed herein, Hepatozoon-associated osteomyelitis is most consistent with the changes seen in USNM 18313.

In summary, the bony lesions exhibited by USNM 18313 are not fully explained by any one etiology, but have features inclusive and exclusive of both osteomyelitis-most closely that associated with Hepatozoon-and hypertrophic osteopathy. The character of the lesions, including the nodular or crateriform shape and the asymmetrical distribution, is more reminiscent of an infectious etiology (e.g., Rothschild and Martin, 2006, figs. 13-1-3). However, the sparing of the axial skeleton and joints, and the proliferative rather than destructive nature of the lesions, is more consistent with hypertrophic osteopathy.

It is certainly possible, perhaps likely, that the specific pathogen involved in the condition of USNM 18313 is no longer extant. Indeed, mirroring the evolution of tetrapods, it is reasonable to assume that many pathogens that were widespread during the Triassic are extinct now, and likewise that many of those commonly causing disease in the modern day were nonexistent when phytosaurs such as USNM 18313 were alive. The expected behavior of modern pathogens, such as Salmonella and Hepatozoon-i.e., where in the body they manifest their effects and what physiologic responses they elicit-may not inform the same behaviors in ancient pathogens of the Triassic. Similarly, metabolic or idiopathic conditions such as hypertrophic osteopathy may have been different or more common during the Triassic, although we agree with Beatty and Rothschild (2009) that certain immune responses are likely deeply rooted within Amniota, if not Tetrapoda or Vertebrata. Both osteomyelitis and hypertrophic osteopathy are rarely reported in extant reptiles, but the ubiquity and timelessness of pathogens generally makes disseminated osteomyelitis a more distinct probability. If the slow metabolic rate and speed of healing of extant reptiles can be translated to extinct ones, then prolonged survival, allowing for bony proliferation in response to infectious niduses, is the most plausible possibility.

\section{SIGNIFICANCE AND DISCUSSION}

Tanke and Rothschild (2002) reviewed the published record of pathologies in dinosaurs, and Rothschild and Martin (2006; see also Beatty and Rothschild, 2009) presented an overview of paleopathological practice as a whole. This paper is narrower in scope, but we note a few interesting aspects of how the specimen described here affects these reviews.

\section{Paleopathologies in Phytosaurs}

This specimen records only the third instance of phytosaur postcranial paleopathology reported in the literature and is by far the most extensive. The first instance consists of two pairs of fused vertebrae first described by Huene (1922) and rediagnosed as spondyloarthropathy by Witzmann et al. (2014). The second to be described is a fractured and healed radius from the Upper Triassic of Wyoming reported by Mehl (1928, pl. 37, fig. 3). By contrast, nearly all previous reports of phytosaur skull pathologies, principally involving the narial crest of various skulls from the Upper Triassic of Germany (e.g., Huene, 1911; Moodie, 1918; Abel, 1922; Gregory, 1962), instead actually describe nonpathological morphologies (Moodie, 1922; Hungerbühler, 2002; Witzmann et al., 2014). Indeed, as reviewed by Hungerbühler (2002, p. 394), only a single phytosaur skull bears obvious pathological bone growth (Huene, 1911, pl. 13, figs. 1, 3; Hungerbühler, 2002, fig. 2D). Unfortunately, no postcrania are associated with this specimen, and the published illustrations are inadequate to provide a reasonable diagnosis. Thus, the fossil we describe here is the most extensively pathological known phytosaur specimen, whether counting by number of affected elements (at least eight) or total number of lesions (many), although it is likely that the pathologies here represent a single etiological event. Still, it is clear that the animal survived for a significant period of time (at least months and possibly years) with this condition, and indeed the presence of the infection is the only evidence supporting the hypothesis that it may have died of complications related to it. The numerous lines of arrested growth (LAGs) evident on the humeral cross-section (Figure 7) corroborate that this phytosaur was slow-growing, and thus probably had a 
relatively low basal metabolic rate, as proposed for other phytosaurs based on histological evidence (de Ricqlés et al., 2003). This evidence further supports our supposition that USNM 18313 lived for multiple months, if not years, with this condition.

\section{Paleopathologies in Other Non-dinosaurian Archosauriforms}

We are aware of only three other Late Triassic instances of pathological non-dinosaurian archosaurs. Drumheller et al. (2014) documented a series of bite marks, some healed and others possibly reflecting scavenging rather than predation, on the femora of two poposaurid paracrocodylomorphs from western North America. There was no indication of infection on either femur, and Drumheller et al. (2014) attributed the bite marks to either phytosaurs or conspecifics. A specimen of the aetosaur Paratypothorax from the Upper Triassic of Germany preserves extensive exostoses encompassing and effectively fusing or coalescing three paramedian osteoderms (Lucas, 2000). Lucas (2000) did not diagnose this specimen beyond a probable "infection after an injury" (p. 1), or "osteoblastic reaction" (p. 5). We note that the "filigree texture," massive bony overgrowth, and presence of draining sinuses or similar structures (Lucas, 2000, fig. 2a-b) are all indicative of osteomyelitis, so we tentatively include this specimen in our list of fossil archosaurs afflicted with the condition, pending further analysis. Additionally, Heckert et al. (2010) documented two possibly pathological elements of the aetosaur Typothorax, including a left radius with an irregular texture and ventral excavation and a foreshortened and thickened right MT IV that they (Heckert et al., 2010, fig. 5a) interpreted as a possible healed fracture. An additional instance of Triassic paleopathology is a case of spondyloarthritis in an archosauriform of Early Triassic age from South Africa (Cisneros et al., 2010), although this specimen almost certainly lies outside of crown Archosauria and stemward of the phytosaur described here.

Relative to dinosaurs, the literature on crocodylian paleopathology is scant. The only documented occurrences of osteomyelitis in fossil crocodylians are in the Paleocene Leidyosuchus formidabilis (Sawyer and Erickson, 1998), although there are other cases that we suspect involve osteomyelitis (e.g., Katsura, 2004). Sawyer and Erickson (1998, figs. 5a-b, 6,10, table 5) documented osteomyelitis in seven elements (atlas, dorsal vertebra, cervical rib, radius, ilium, femur, tibia) from an unknown number of individuals out of a total of at least 80 individuals represented by 7,154 elements, including osteoderms. Extensive hyperreactive bone surfaces and apparent drainage tracts similarly characterize parts of the mandible, tibia, and fibula in the holotype of the Pleistocene crocodile Toyotamaphimeia machikanensis (Katsura 2004, figs. 1, 2).

Pathologies also have been documented in pterosaurs, the best-known ornithodiran archosaur clade exclusive of dinosaurs. Bennett (2003) summarized the known paleopathologies of large pterosaurs but provided only generalized diagnoses. Thus, some of the conditions he identified as necroses (13 instances) and bony overgrowths (four instances) may well include instances of osteomyelitis, but the descriptions and illustrations provided are inadequate for more specific diagnoses in most cases.

\section{Paleopathologies in Dinosaurs}

Aside from hominids, dinosaurs in general and theropods in particular have received by far the most attention with respect to documenting paleopathological specimens (Rothschild, 1997; Tanke and Rothschild, 2002; Rothschild and Martin, 2006), perhaps at the expense of other taxa. Still, dinosaurs are, along with other ornithodirans, the sister taxon to the Crurotarsi, of which phytosaurs are often recovered as an early-diverging clade, so these records are still relevant to our study. This is especially true given that documented instances of paleopathology in crocodylians are comparatively rare, leaving the dinosaurian record as the best way to assess the possible phylogenetic significance of the paleopathological record in archosaurs. In the following paragraphs we evaluate this phytosaur in the context of the fossil record of osteomyelitis in nonavian archosaurs, acknowledging that the record of dinosaurs is almost certainly under-reported, either because affected elements were not preserved in recovered specimens or, as in this case, have not yet been recognized.

Because Triassic dinosaurs are rare, their pathologies are similarly uncommon-in fact, nearly unknown at this time (Tanke and Rothschild, 2002). This near-total absence is somewhat surprising given the existence of large quarry samples for some taxa that have been examined in detail, including Coelophysis from Ghost Ranch (e.g., Colbert, 1990; Weishampel and Chapman, 1990; Rinehart et al., 2009) and Plateosaurus from Trossingen, Halberstadt, and Hallau (e.g., Schoch, 2011). Of these hundreds of Triassic dinosaur skel- 
etons, the paleopathological record is limited to healed fractures in the gastralia of some specimens of Plateosaurus (Sander, 1992), one element of the sauropodomorph Camelotia (Galton, 1998; Tanke and Rothschild, 2002), an abnormal distal tibia in the herrerasaurid Sanjuansaurus (Alcober and Martinez, 2010), and a neotheropod fibula (Griffin, 2018). Pathologies are also apparent in some Triassic dinosaur footprints (McCrea et al., 2015), but these present numerous additional diagnostic hurdles.

At first glance, Tanke and Rothschild (2002, appendix two) document numerous cases of Jurassic and Cretaceous dinosaurs afflicted by osteomyelitis in the literature. However a careful review of their sources reveals much duplication, where multiple authors have reported the same instance of a pathology, so while their literature review is comprehensive, there are fewer paleopathological specimens, especially those indicating osteomyelitis, than it at first appears. For example, Rothschild et al. (1997b), Rega and Brochu (2001), Larson (2001), and Wolff et al. (2009) all described pathologies, including osteomyelitis, in the same individual of Tyrannosaurus rex (FMNH PR 2081; later substantiated by Brochu, 2003 and Hamm et al., 2020). We also discount occurrences only published in abstract form (e.g., Marshall et al., 1997) unless substantiated by later publications (e.g., Rega and Brochu, 2001, Brochu, 2003). Additionally, some instances of osteomyelitis recorded in earlier literature (e.g., the Troodon reported by Rothschild [1997] as "Molnar, in press") were not substantiated by later papers (e.g., Molnar, 2001). This leaves the dinosaurian record with only a few bona fide, peer-reviewed reports of osteomyelitis (Table 2). To this record we add a second, inverse caveat: many paleopathologies have likely gone unreported, simply because their presence has gone unnoticed or has been considered undeserving of mention in a publication.

Of the formally documented examples, only three theropods-one specimen of Tyrannosaurus rex ("Sue," FMNH PR 2081; Brochu, 2003), one of Allosaurus ("Big Al," MOR 693; Hanna, 2002), and another of Dilophosaurus (Senter and Juengst, 2016) show multiple, discrete lesions on distinct elements-all other confirmed cases consist of individual elements (or articulated and/or closely associated elements) responding to a single traumatic event. In both the Tyrannosaurus and Allosaurus cases, multiple pathological elements appear to reflect a single event. Brochu (2003) noted pathologies he interpreted as possible osteo- myelitis on the right humerus and left fibula of FMNH PR 2081, of which the latter is the most volumetrically impressive (Brochu, 2003, fig. 97a-b; Hamm et al., 2020, fig. 1g-h, 2-3). Other pathological elements with extensive exostoses include the left surangular and many ribs (13-15 on the right side, 17-21 on the left), although Brochu (2003) did not diagnose many of these further, noting only that the surangular lesions appear grossly similar to those of the humerus and one of the ribs, and that several of the ribs were obviously broken and healed. Wolff et al. (2009) later diagnosed the surangular lesions as deriving from a trichomonosis infection, rather than bite wounds or actinomycosis. Similarly, Hanna (2002) documented 19 skeletal abnormalities in MOR 693 but interpreted them as probably reflecting a much smaller number of events befalling that individual of Allosaurus. Incidentally Foth et al. (2015) did not explicitly diagnose osteomyelitis in another, similarly pathological Allosaurus specimen ("Big Al 2," SMA 005). Finally, Senter and Juengst (2016) documented an array of pathologies on eight elements of the pectoral girdle and forelimbs of Dilophosaurus, although only two elements (the left ulna and the proximal phalanx of digit I) were diagnosed as experiencing osteomyelitis.

\section{Paleobiological Implications}

What is striking is the comparison of elements infected in this phytosaur relative to other archosaurs, especially dinosaurs. To date no study has confirmed the presence of a major pathology on a theropod dinosaur femur, and in general the primary weight-bearing elements of dinosaurs (humerus, femur, and tibia) only infrequently show evidence of injury (Molnar, 2001; Tanke and Rothschild, 2002). The few published femoral pathologies we are aware of in non-avian dinosaurs are tumors, such as those reported in the stegosaur Gigantspinosaurus (Hau et al., 2018) and sauropod Bonitasaura (Gonzalez et al., 2017). By contrast, injuries to these elements are much more common in crocodylians (Katsura, 2004). Previous authors have interpreted this distribution, as well as the absence of major trauma to the flight apparatus in pterosaurs (e.g., Bennett, 2003), as evidence that major locomotor elements in Mesozoic archosaurs were extremely resistant to trauma and/or that injuries or pathologies in these elements were usually fatal. Certainly both theropods and pterosaurs would have been unable to compensate for the disuse of one of the main propulsive limbs; quadrupedal dinosaurs may not have 
HeCKert, VineR, \& CARRANo: PATHOlogical PHytosaur

TABLE 2. Instances of osteomyelitis in the literature of Mesozoic fossil archosaurs, listed in approximate stratigraphic order.

\begin{tabular}{|c|c|c|c|c|}
\hline Age & Taxon & Element(s) & $\begin{array}{c}\text { References and other } \\
\text { notes }\end{array}$ & Specimen(s) \\
\hline Late Cretaceous & $\begin{array}{l}\text { Majungasaurus } \\
\text { crenatissimus }\end{array}$ & $\begin{array}{l}\text { amputated tail, also } \\
\text { possibly a left pedal } \\
\text { phalanx }\end{array}$ & Farke and O'Connor (2007) & FMNH PR 2294 \\
\hline Late Cretaceous & Hadrosaur & tibia & $\begin{array}{l}\text { Tanke in Tanke and } \\
\text { Rothschild (2002) }\end{array}$ & CMN 41201 \\
\hline Late Cretaceous & Edmontosaurus annectens & $\begin{array}{l}\text { left metacarpals III and } \\
I^{*}\end{array}$ & $\begin{array}{l}\text { Moodie (1926), Rothschild } \\
\text { (1997) }\end{array}$ & USNM 3814 \\
\hline Late Cretaceous & Ankylosaurids & vertebrae & $\begin{array}{l}\text { Arbour and Currie (2011); } \\
\text { osteomyelitis or other } \\
\text { conditions }\end{array}$ & Various \\
\hline Late Cretaceous & Tyrannosaurus rex (“Sue”) & humerus and tibia & $\begin{array}{l}\text { Larson (2001), Rega and } \\
\text { Brochu (2001), Brochu } \\
\text { (2002) }\end{array}$ & FMNH PR 2081 \\
\hline Late Cretaceous & Tyrannosaurus rex & phalanx I-1 & $\begin{array}{l}\text { Rothschild et al. ( } 1997 \mathrm{~b}) \text {; } \\
\text { infection preceded by gout }\end{array}$ & TMP 92.36.328 \\
\hline Late Cretaceous & Tyrannosaurus rex (“Jane") & pedal phalanx & $\begin{array}{l}\text { Vittore and Henderson } \\
\text { (2013) }\end{array}$ & BMR P2002.4.1 \\
\hline Late Cretaceous & Titanosauridae indet. & caudal vertebrae & García et al. (2017) & MCS-PV 183 \\
\hline Early Cretaceous & Tenontosaurus tilletti & $\begin{array}{l}\text { dorsal rib, metacarpal } \\
\text { IV }\end{array}$ & Hunt et al. (2019) & OMNH 58340 \\
\hline Early Cretaceous & $\begin{array}{l}\text { Leaellynasaura } \\
\text { amicagraphica }\end{array}$ & tibia & $\begin{array}{l}\text { Gross et al. (1993), Hanna } \\
(2000) \text {; Woodward et al., } \\
(2018)\end{array}$ & NMV P186047 \\
\hline Late Jurassic & Stegosaurus spp. & tail spikes & $\begin{array}{l}\text { McWhinney et al., (2001) } \\
\text { and references therein; at } \\
\text { least two individuals }\end{array}$ & DMNH 2818; USNM 6646 \\
\hline Late Jurassic & Camptosaurus dispar & ilium & $\begin{array}{l}\text { Moodie (1917), Rothschild } \\
\text { (1997) }\end{array}$ & USNM 4282 \\
\hline Late Jurassic & Allosaurus fragilis & & $\begin{array}{l}\text { Peterson et al. (1972); } \\
\text { Hanna (2002); Tanke and } \\
\text { Rothschild (2002); multiple } \\
\text { individuals from } \\
\text { Cleveland-Lloyd Quarry }\end{array}$ & $\begin{array}{l}\text { UMNH VP } 1657,1528, \\
5599 \text { (up to } 5 \text { elements) }\end{array}$ \\
\hline Late Jurassic & $\begin{array}{l}\text { Allosaurus jimmadseni } \\
\text { ("Big Al”) }\end{array}$ & multiple elements & Hanna (2002) & MOR 693 \\
\hline Late Triassic & $\begin{array}{l}\text { Paratypothorax } \\
\text { andressorum }\end{array}$ & $\begin{array}{l}\text { three caudal dorsal } \\
\text { paramedian } \\
\text { osteoderms }\end{array}$ & $\begin{array}{l}\text { Lucas (2000); Desojo et al. } \\
(2013)\end{array}$ & SMNS 12598 \\
\hline
\end{tabular}

*Reported by Moodie (1926), but the diagnosis of osteomyelitis is from Rothschild (1997). The lack of crateriform lesions and Moodie's description of the concentric arrangement around vascular channels suggests that this may be callus development associated with fracture repair.

Acronyms: BMR, Burpee Museum of Natural History, Rockford; CMN = Canadian Museum of Nature, Ottawa; DMNH = Denver Museum of Nature and Science; FMNH = Field Museum of Natural History, Chicago; MCS-Pv, Palaeovertebrate collection of the Museo de Cinco Saltos, Río Negro, Argentina; NMV = National Museum of Victoria, Melbourne; SMNS = Staatliches Museum für Naturkunde, Stuttgart; TMP = Tyrell Museum of Paleontology, Drumheller; USNM = National Museum of Natural History (Smithsonian Institution), Washington, DC; UMNH = Utah Museum of Natural History, Salt Lake City.

faced so severe a constraint. It is possible that some combination of the sprawling, quadrupedal posture of phytosaurs, their presumed, semiaquatic lifestyle, and their possibly ectothermic physiology rendered these pathologies more sur- vivable (and thus preservable) than in theropods. Similarly, at least one of the poposaurids described by Drumheller et al. (2014) also survived an attack that damaged the femur at least long enough for the resulting bite marks to initiate healing. Indeed, 
TABLE 3. Incidences of osteomyelitis in necropsied animals, U.S. National Zoo, 1980-2008. Note that Sauropsida in this database includes Crocodylia but excludes Aves.

\begin{tabular}{lccc}
\hline \multicolumn{1}{c}{ Taxon } & Instances & $\begin{array}{c}\text { Total } \\
\text { necropsies }\end{array}$ & Percentage \\
\hline Sauropsida & 12 & 2230 & $0.54 \%$ \\
Crocodylia & 1 & 35 & $2.86 \%$ \\
Aves & 63 & 6307 & $1.0 \%$ \\
Mammalia & 80 & 7703 & $1.0 \%$ \\
\hline
\end{tabular}

Katsumo (2004) provided a good summary of the apparent survivability of modern crocodilians in spite of grievous injuries to the appendicular skeleton. This observation would seem to be corroborated by this specimen, which records more pathology to major weight-bearing, propulsive bones (humerus, both femora) than have been recorded for all of Dinosauria to date.

Accurately documenting the incidence of pathologies in extant populations is extremely difficult, and, even if possible, may not be particularly relevant to the Mesozoic. Reports of bony lesions of any etiology in extant reptiles are scant. Citations of osteomyelitis and osteoarthritis in reptiles, though few in number, overwhelmingly involve captive populations. Zoo records afford a window into the health of a wide range of taxa which, although not wild, may at least reflect phylogenetic tendency or susceptibility to disease. Additionally, the Smithsonian National Zoo database records the results of 16240 necropsies of amniotes dating back to 1980 (Table 3); these include only a single instance of osteomyelitis out of 35 crocodilian necropsies $(\sim 3 \%)$, and much lower rates in other reptiles, birds, and mammals (Table 3 ).

\section{CONCLUSIONS}

The phytosaur specimen documented here, USNM 18313, was recovered from strata of Adamanian (early-mid-Norian) age near Saint Johns, Arizona, and is best assigned to Smilosuchus gregorii, a species known from two other large, robust skulls. USNM 18313 comprises one of the betterpreserved phytosaur postcranial skeletons, and the best known for S. gregorii, but the appendicular skeleton includes at least eight elements with significant paleopathological alteration. These alterations, which include numerous exophytic lesions, often with central cavitation and formation of Codman's triangles, and resorption or other alteration of the architecture of the most affected elements, strongly resemble features often diagnosed as osteomyelitis in the paleopathological literature. However, osteomyelitis typically affects the axial skeleton, which is incompletely preserved but apparently unaffected in USNM 18313. Thus, these lesions could also be interpreted as resulting from hypertrophic osteopathy, which would be restricted to the limbs but typically exhibits symmetrical lesions. Based on either the number of affected elements or the total extent of diseased bone, USNM 18313 is the single most pathological specimen not only of a phytosaur, but of any Triassic archosauriform. Depending on the phylogenetic placement of Phytosauria, it may also be one of the most pathological crurotarsan (crocodile-line) fossil archosaurs known. The preservation of paleopathological femora in this specimen, compared to its extreme rarity in non-avian dinosaurs, supports interpretations of phytosaurs as semi-aquatic predators (for which individual limb support was less critical). While osteomyelitis is one of the most commonly recognized paleopathologies, especially in dinosaurs, we urge caution in interpreting it, especially as it is understudied in the primary veterinary literature and almost unknown in wild populations.

\section{ACKNOWLEDGMENTS}

B. Froehlich and D. Hunt of the Department of Anthropology, National Museum of Natural History (NMNH) performed the CT-scanning. The resulting data were rendered by $\mathrm{D}$. White (Department of Paleobiology, NMNH), who also developed the videos published herein. J. Wingerath (Department of Paleobiology, NMNH) skillfully produced the thinsection shown in Figure 7 and provided details on thin-section methodology. We thank S.M. Willis (Department of Exhibits, NMNH) for the skeletal drawing used in Figure 4, which is used here courtesy of the Smithsonian Institution. TV compiled the data in Table 3 while a pathologist at the US National Zoo. Comments received on a poster at the 2008 Society of Vertebrate Paleontology meeting, especially by Bruce Rothschild, were very helpful. Discussion with E. Wolff was important in developing some aspects of this paper. The findings and conclusions in this article are those of the authors and do not necessarily represent the views of the U.S. Fish and Wildlife Service. We are indebted to three anonymous reviewers and Editor C. Kammerer for valuable comments that improved the manuscript. 


\section{REFERENCES}

Abel, O. 1922. Die Schnauzenverletzungen der Parasuchier und ihre biologische Bedeutung. Paläontologische Zeitschrift, 5:26-57.

Alcober, O. and Martinez, R.N. 2010. A new herrerasaurid (Dinosauria, Saurischia) from the Upper Triassic Ischigualasto Formation of northwestern Argentina. ZooKeys, 63:55-81. https://doi.org/10.3897/zookeys.63.550

Arbour, V.M. and Currie, P.J. 2011. Tail and pelvis pathologies of ankylosaurian dinosaurs. Historical Biology, 23:375-390. https://doi.org/10.1080/08912963.2011.563849

Ash, S.R. 1987. The Upper Triassic red bed flora of the Colorado Plateau, western United States. Journal of the Arizona-Nevada Academy of Science, 22:95-105.

Ballew, K.L. 1989. A phylogenetic analysis of Phytosauria from the Late Triassic of the western United States, p. 309-339. In Lucas, S.G. and Hunt, A.P. (eds.), Dawn of the Age of Dinosaurs in the American Southwest. New Mexico Museum of Natural History, Albuquerque.

Barten, S.L. 2000. What's your diagnosis? Journal of Herpetological Medicine and Surgery, 10:48-50.

Beatty, B.L. and Rothschild, B.M. 2009. Paleopathologies are features of an organism and its interaction with the environment and should not be treated like organisms unto themselves. Historical Biology, 21:229-233. https://doi.org/10.1080/08912960903469711

Bemis, D.A., Grupka, L.M., Liamthong, S., Folland, D.W., Sykes, J.M., IV, and Ramsay, E.C. 2007. Clonal relatedness of Salmonella isolates associated with invasive infections in captive and wild-caught rattlesnakes. Veterinary Microbiology, 120:300-307. https://doi.org/10.1016/j.vetmic.2006.10.028

Bennett, S.C. 2003. A survey of pathologies of large pterodactyloid pterosaurs. Palaeontology, 46:185-198. https://doi.org/10.1111/1475-4983.00293

Benton, M.J. and Clark, J.M. 1988. Archosaur phylogeny and the relationships of the Crocodylia, p. 295-338. In Benton, M.J. (ed.), The Phylogeny and Classification of the Tetrapods. Clarendon Press, Oxford.

Brochu, C.A. 2002. Osteology of Tyrannosaurus rex: Insights from a nearly complete skeleton and high-resolution computed tomographic analysis of the skull. Society of Vertebrate Paleontology Memoir, Journal of Vertebrate Paleontology, 22(sup. 2), 7:138.

Butler, R.J., Jones, A.S., Buffetaut, E., Mandl, G.W., Scheyer, T.M., and Schultz, O. 2019. Description and phylogenetic placement of a new marine species of phytosaur (Archosauriformes: Phytosauria) from the Late Triassic of Austria. Zoological Journal of the Linnean Society, 187:198-228. https://doi.org/10.1093/zoolinnean/zlz014

Camp, C.L. 1930. A study of the phytosaurs with description of new material from western North America. Memoirs of the University of California, 19:174.

Cisneros, J.C., Gomes Cabral, U., de Beer, F., Damiani, R., and Costa Fortier, D. 2010. Spondarthritis in the Triassic. PLOS One, 5(10):e13425. https://doi.org/10.1371/journal.pone.0013425

Colbert, E.H. 1947. Studies of the phytosaurs Machaeroprosopus and Rutiodon. Bulletin of the American Museum of Natural History, 88:53-96.

Colbert, E.H. 1990. Variation in Coelophysis, p. 80-90. In Carpenter, K. and Currie, P.J. (eds.), Dinosaur Systematics: Approaches and Perspectives. Cambridge University Press, Cambridge.

de Ricqlés, A.J., Padian, K., and Horner, J.R. 2003. On the bone histology of some Triassic pseudosuchian archosaurs and related taxa. Annales de Paléontologie, 89:67-101. https://doi.org/10.1016/S0753-3969(03)00005-3

Desojo, J.B., Heckert, A.B., Martz, J.W., Parker, W.G., Schoch, R.R., Small, B.J., and Sulej, T. 2013. Aetosauria: a clade of armoured pseudosuchians from the Upper Triassic continental beds, p. 203-239. In Nesbitt, S.J., Desojo, J.B., and Irmis, R.B. (eds.), Phylogeny and Palaeobiology of Early Archosaurs and Their Kin. Geological Society, London, Special Publications, 379. https://doi.org/10.1144/SP379.17

Doyle, K.D. and Sues, H.-D. 1995. Phytosaurs (Reptilia: Archosauria) from the Upper Triassic New Oxford Formation of York County, Pennsylvania. Journal of Vertebrate Paleontology, 15:545-553. https://doi.org/10.1080/02724634.1995.10011247 
Drumheller, S.K., Stocker, M.R., and Nesbitt, S.J. 2014. Direct evidence of trophic interactions among apex predators in the Late Triassic of western North America. Naturwissenschaften, 101:975-987. https://doi.org/10.1007/s00114-014-1238-3

Ekhtiari, S., Chiba, K., Popovic, S., Crowther, R., Wohl, G., Kin On Wong, A., Tanke, D.H., Dufault, D.M., Geen, O.D., Parasu, N., Crowther, M.A., and Evans, D.C. 2020. First case of osteosarcoma in a dinosaur: a multimodal diagnosis. The Lancet Oncology, 21:1021-1022. https://doi.org/10.1016/S1470-2045(20)30171-6

Ewald, P.W. and Swain Ewald, H.A. 2015. Infection and cancer in multicellular organisms. Philosophical Transactions of the Royal Society B: Biological Sciences, 370:20140224. https://doi.org/10.1098/rstb.2014.0224

Ezcurra, M.D. 2016. The phylogenetic relationships of basal archosauromorphs, with an emphasis on the systematics of proterosuchian archosauriforms. PeerJ, 4:e1778. https://doi.org/10.7717/peerj.1778

Farke, A.A. and O'Connor, P.M. 2007. Pathology in Majungasaurus crenatissimus (Theropoda: Abelisauridae) from the Late Cretaceous of Madagascar. Society of Vertebrate Paleontology Memoir, Journal of Vertebrate Paleontology, 27(sup. 2):180-184. https://doi.org/10.1671/0272-4634(2007)27[180:PIMCTA]2.0.CO;2

Foth, C., Evers, S.W., Pabst, B., Mateus, O., Flisch, A., Patthey, M., and Rauhut, O.W. 2015. New insights into the lifestyle of Allosaurus (Dinosauria: Theropoda) based on another specimen with multiple pathologies. PeerJ, 3:e940. https://doi.org/10.7717/peerj.940

García, R.A., Cerda, I.A., Heller, M., Rothschild, B.M., and Zurriaguz, V. 2017. The first evidence of osteomyelitis in a sauropod dinosaur. Lethaia, 50:227-236. https://doi.org/10.1111/let.12189

Galton, P.M. 1998. Saurischian dinosaurs from the Upper Triassic of England: Camelotia (Prosauropoda, Melanorosauridae) and Avalonianus (Theropoda, ?Carnosauria). Palaeontographica Abteilung A, 250:155-172.

Gonzalez, R., Gallina, P.A., and Cerda, I.A. 2017. Multiple paleopathologies in the dinosaur Bonitasaura salgadoi (Sauropoda: Titanosauria) from the Upper Cretaceous of Patagonia, Argentina. Cretaceous Research, 79:159-170. https://doi.org/10.1016/j.cretres.2017.07.013

Gregory, H.E. 1917. Geology of the Navajo Country: a reconnaissance of parts of Arizona, New Mexico, and Utah. United States Geological Survey Professional Paper, 93:161.

Gregory, J.T. 1962. The genera of phytosaurs. American Journal of Science, 260:652-690.

Griffin, C.T. 2018. Pathological bone tissue in a Late Triassic neotheropod fibula, with implications for the interpretation of medullary bone. New Jersey State Museum Investigations, 6:1-10.

Gross, J.D., Rich, T.H., and Vickers-Rich, P. 1993. Dinosaur bone infection. National Geographic Research, 9:286-293.

Grupka, L.M., Ramsay, E.C., and Bemis, D.A. 2006. Salmonella surveillance in a collection of rattlesnakes (Crotalus spp.). Journal of Zoological Wildlife Medicine, 37:306-312. https://doi.org/10.1638/05-059.1

Hamm, C.A., Hampe, O., Schwarz, D., Witzmann, F., Makovicky, P.J., Brochu, C.A., Reiter, R., and Asbach, P. 2020. A comprehensive diagnostic approach combining phylogenetic disease bracketing and CT imaging reveals osteomyelitis in a Tyrannosaurus rex. Scientific Reports, 10(1):18897. https://doi.org/10.1038/s41598-020-75731-0

Hanna, R.R. 2000. Dinosaurs got hurt, too, p. 119-126. In Paul, G.S. (ed.), The Scientific American Book of Dinosaurs. St. Martin's Press, New York.

Hanna, R.R. 2002. Multiple injury and infection in a sub-adult theropod dinosaur Allosaurus fragilis with comparisons to allosaur pathology in the Cleveland-Lloyd dinosaur quarry collection. Journal of Vertebrate Paleontology, 22:76-90. https://doi.org/10.1671/0272-4634(2002)022[0076:MIAIIA]2.0.CO;2

Hao, B.-Q., Ye, Y., Maidment, S.C.R., Bertazzo, S., Peng, G.-Z., and You, H.-L. 2018. Femoral osteopathy in Gigantspinosaurus sichuanensis (Dinosauria: Stegosauria) from the Late Jurassic of Sichuan Basin, Southwestern China. Historical Biology, 32:1028-1035. https://doi.org/10.1080/08912963.2018.1561673

Haridy, Y., Witzmann, F., Asbach, P., Schoch, R.R., Fröbisch, N., and Rothschild, B.M. 2019. Triassic Cancer-Osteosarcoma in a 240-Million-Year-Old Stem-Turtle Triassic CancerOsteosarcoma in a 240-Million-Year-Old Stem-Turtle Letters. JAMA Oncology, 5:425-426. https://doi.org/10.1001/jamaoncol.2018.6766 
Heckert, A.B. 2002. A revision of the Upper Triassic ornithischian dinosaur Revueltosaurus, with a description of a new species. New Mexico Museum of Natural History and Science Bulletin, 21:253-268.

Heckert, A.B. 2004. Late Triassic microvertebrates from the lower Chinle Group (OtischalkianAdamanian: Carnian), southwestern U.S.A. New Mexico Museum of Natural History and Science Bulletin, 27:1-170.

Heckert, A.B. 2005. Krzyzanowskisaurus, a new name for a probable ornithischian dinosaur from the Upper Triassic Chinle Group, Arizona and New Mexico. New Mexico Museum of Natural History and Science Bulletin, 29:77-83.

Heckert, A.B. and Lucas, S.G. 2000. Taxonomy, phylogeny, biostratigraphy, biochronology, paleobiogeography, and evolution of the Late Triassic Aetosauria (Archosauria: Crurotarsi). Zentralblatt für Geologie und Paläontologie, Teil I, 1998(11-12):1539-1587.

Heckert, A.B. and Lucas, S.G. 2001. Stratigraphy, biostratigraphy, and biochronology of lower Chinle Group (Adamanian: latest Carnian) vertebrate fossil assemblages in the vicinity of St. Johns, Arizona. Southwest Paleontological Symposium Proceedings:9-15.

Heckert, A.B. and Lucas, S.G. 2002a. Osteoderms of juveniles of Stagonolepis (Archosauria: Aetosauria) from the lower Chinle Group, east-central Arizona. New Mexico Museum of Natural History and Science Bulletin, 21:235-239.

Heckert, A.B. and Lucas, S.G. 2002b. Acaenasuchus geoffreyi (Archosauria:Aetosauria) from the Upper Triassic Chinle Group: Juvenile of Desmatosuchus haplocerus. New Mexico Museum of Natural History and Science Bulletin, 21:205-214.

Heckert, A.B. and Lucas, S.G. 2003. Stratigraphy and paleontology of the lower Chinle Group (Adamanian: latest Carnian) in the vicinity of St. Johns, Arizona. New Mexico Geological Society Guidebook, 54:281-288.

Heckert, A.B. and Lucas, S.G. 2006. Micro- and small vertebrate biostratigraphy and biochronology of the Upper Triassic Chinle Group, southwestern USA. New Mexico Museum of Natural History and Science Bulletin, 37:94-104.

Heckert, A.B. and Miller-Camp, J.A. 2013. Tooth enamel microstructure of Revueltosaurus and Krzyzanowskisaurus (Reptilia: Archosauria) from the Upper Triassic Chinle Group, USA: Implications for function, growth, and phylogeny. Palaeontologia Electronica, 16.1.1A:1-23. https://doi.org/10.26879/319

Heckert, A.B., Lucas, S.G., and Krzyzanowski, S.E. 2002. The rauisuchian archosaur Saurosuchus from the Upper Triassic Chinle Group, southwestern U.S.A. and its biochronological significance. New Mexico Museum of Natural History and Science Bulletin, 21:241-244.

Heckert, A.B., Lucas, S.G., and Hunt, A.P. 2005. Triassic vertebrate fossils in Arizona. New Mexico Museum of Natural History and Science Bulletin, 29:16-44.

Heckert, A.B., Lucas, S.G., Dickinson, W.R., and Mortensen, J.K. 2009. New ID-TIMS U-Pb ages for Chinle Group strata (Upper Triassic) in New Mexico and Arizona, correlation to the Newark Supergroup, and implications for the "long Norian". Geological Society of America Abstracts with Programs, 41(7):123.

Heckert, A.B., Lucas, S.G., Rinehart, L.F., Celeskey, M.D., Spielmann, J.A., and Hunt, A.P. 2010. Articulated skeletons of the aetosaur Typothorax coccinarum Cope (Archosauria: Stagonolepididae) from the Upper Triassic Bull Canyon Formation (Revueltian: early-mid Norian), eastern New Mexico, USA. Journal of Vertebrate Paleontology, 30:619-642. https://doi.org/10.1080/02724631003763524

Hoenerhoff, M., Kiupel, M., Sikarskie, J., Bolin, C., Simmons, H., and Fitzgerald, S. 2004. Mycobacteriosis in an American Bald Eagle (Haliaeetus leucocephalus). Avian Diseases, 48:437-441. https://doi.org/10.1637/7133

Hone, D.W.E. and Tanke, D.H. 2015. Pre- and postmortem tyrannosaurid bite marks on the remains of Daspletosaurus (Tyrannosaurinae: Theropoda) from Dinosaur Provincial Park, Alberta, Canada. PeerJ, 3:e885. https://doi.org/10.7717/peerj.885

Huchzermeyer, F.W. and Cooper, J.E. 2000. Fibriscess, not abscess, resulting from a localised inflammatory response to infection in reptiles and birds. Veterinary Record, 147(18):515. https://doi.org/10.1136/vr.147.18.515

Huene, F.v. 1911. Beitrage zur Kenntnis und Beurteilung der Parasuchier. Geologie und Paläontologie, Abteilung, 10:1-121.

Huene, F.v. 1922. Neue Beitrage zur Kenntnis der Parasuchier. Jahrbuch der Preussischen Geologischen Landesanstalt zu Berlin, 42:59-160. 
Hungerbühler, A. 1998. Cranial anatomy and diversity of the Norian phytosaurs of Southwestern Germany. Ph.D. Thesis, University of Bristol, Bristol.

Hungerbühler, A. 2000. Heterodonty in the European phytosaur Nicrosaurus kapffi and its implications for the taxonomic utility and functional morphology of phytosaur dentitions. Journal of Vertebrate Paleontology, 20:31-48. https://doi.org/10.1671/0272-4634(2000)020[0031:HITEPN]2.0.CO;2

Hungerbühler, A. 2002. The Late Triassic phytosaur Mystriosuchus westphali, with a revision of the genus. Palaeontology, 45:377-418. https://doi.org/10.1111/1475-4983.00242

Hunt, A.P. 1989. Cranial morphology and ecology among phytosaurs, p. 349-354. In Lucas, S.G. and Hunt, A.P. (eds.), Dawn of the Age of Dinosaurs in the American Southwest. New Mexico Museum of Natural History, Albuquerque.

Hunt, A.P. 1993. Revision of the Metoposauridae (Amphibia: Temnospondyli) and description of a new genus from western North America. Museum of Northern Arizona Bulletin, 59:67-97.

Hunt, A.P. 1994. Vertebrate paleontology and biostratigraphy of the Bull Canyon Formation (Chinle Group, Upper Triassic), east-central New Mexico with revisions of the families Metoposauridae (Amphibia: Temnospondyli) and Parasuchidae (Reptilia: Archosauria). Ph.D. Dissertation, University of New Mexico, Albuquerque.

Hunt, A.P. and Lucas, S.G. 1989. New genotype designations for the phytosaurs Mystriosuchus and Rutiodon with a discussion of the taxonomic status of Mystriosuchus, Clepsysaurus and Rutiodon, p. 340-348. In Lucas, S.G. and Hunt, A.P. (eds.), Dawn of the Age of Dinosaurs in the American Southwest. New Mexico Museum of Natural History, Albuquerque.

Hunt, A.P., Lucas, S.G., and Heckert, A.B. 2005. Definition and correlation of the Lamyan: A new biochronological unit for the nonmarine late Carnian (Late Triassic). New Mexico Geological Society Guidebook, 56:357-366.

Hunt, T.C., Peterson, J.E., Frederickson, J.A., Cohen, J.E., and Berry, J.L. 2019. First documented pathologies in Tenontosaurus tilletti with comments on infection in non-avian dinosaurs. Scientific Reports, 9(1):8705. https://doi.org/10.1038/s41598-019-45101-6

Hurlburt, G.R., Heckert, A.B., and Farlow, J.O. 2003. Body mass estimates of phytosaurs (Archosauria: Parasuchidae) from the Petrified Forest Formation (Chinle Group: Revueltian) based on skull and limb bone measurements. New Mexico Museum of Natural History and Science Bulletin, 24:105-113.

Intarapanich, N.P., Touroo, R.M., Rozanski, E.A., Reisman, R.W., Intarapanich, P.P., and McCobb, E.C. 2017. Characterization and comparison of injuries caused by spontaneous versus organized dogfighting. Journal of the American Veterinary Medical Association, 251:1424-1431. https://doi.org/10.2460/javma.251.12.1424

Irmis, R.B. 2005. The vertebrate fauna of the Upper Triassic Chinle Formation in northern Arizona. Mesa Southwest Museum Bulletin, 9:63-88.

Irmis, R.B., Nesbitt, S.J., Padian, K., Smith, N.D., Turner, A.H., Woody, D., and Downs, A. 2007. A Late Triassic dinosauromorph assemblage from New Mexico and the rise of dinosaurs. Science, 317:358-361. https://doi.org/10.1126/science.1143325

Irmis, R.B., Mundil, R., Martz, J.W., and Parker, W.G. 2011. High-resolution U-Pb ages from the Upper Triassic Chinle Formation (New Mexico, USA) support a diachronous rise of dinosaurs. Earth and Planetary Science Letters, 309:258-267. https://doi.org/10.1016/ j.epsl.2011.07.015

Irwin, C.R. and Ferguson, M.W.J. 1986. Fracture repair of reptilian dermal bones: can reptiles form secondary cartilage? Journal of Anatomy, 146:53-64.

Jacobson, E. 2007. Bacterial diseases of reptiles, p. 461-562. In Jacobson, E.R. (ed.), Infections diseases and pathology of reptiles. CRC press, Boca Raton, FL.

Jones, A.S. and Butler, R.J. 2018. A new phylogenetic analysis of Phytosauria (Archosauria: Pseudosuchia) with the application of continuous and geometric morphometric character coding. PeerJ, 6:e5901. https://doi.org/10.7717/peerj.5901

Juul, L. 1994. The phylogeny of basal archosaurs. Palaeontologia Africana, 31:1-38.

Kammerer, C.F., Butler, R.J., Saswati, B., and Stocker, M.R. 2016. Relationships of the Indian phytosaur Parasuchus hislopi Lydekker, 1885. Papers in Palaeontology, 2:1-23. https://doi.org/10.1002/spp2.1022

Kato, K.M., Rega, E.A., Sidor, C.A., and Huttenlocker, A.K. 2020. Investigation of a bone lesion in a gorgonopsian (Synapsida) from the Permian of Zambia and periosteal reactions in fossil non-mammalian tetrapods. Philosophical Transactions of the Royal Society B: Biological Sciences, 375(1793):20190144. https://doi.org/10.1098/rstb.2019.0144 
Katsura, Y. 2004. Paleopathology of Toyotamaphimeia machikanensis (Diapsida, Crocodylia) from the Middle Pleistocene of central Japan. Historical Biology, 16:93-97. https://doi.org/10.1080/08912963400015041

Larson, P. 2001. Paleopathologies in Tyrannosaurus rex. Dinopress, 5:26-37.

Lessner, E.J. and Stocker, M.R. 2017. Archosauriform endocranial morphology and osteological evidence for semiaquatic sensory adaptations in phytosaurs. Journal of Anatomy, 231:655664. https://doi.org/10.1111/joa.12668

Lingham-Soliar, T. 2004. Palaeopathology and injury in the extinct mosasaurs (Lepidosauromorpha, Squamata) and implications for modern reptiles. Lethaia, 37:255-262. https://doi.org/10.1080/00241160410006519

Long, R.A. and Ballew, K.L. 1985. Aetosaur dermal armor from the Late Triassic of southwestern North America, with special reference to material from the Chinle Formation of Petrified Forest National Park. Museum of Northern Arizona Bulletin, 47:45-68.

Long, R.A. and Murry, P.A. 1995. Late Triassic (Carnian and Norian) tetrapods from the southwestern United States. New Mexico Museum of Natural History and Science Bulletin, $4: 254 \mathrm{p}$.

Lucas, S.G. 1993. The Chinle Group: Revised stratigraphy and biochronology of Upper Triassic strata in the western United States. Museum of Northern Arizona, Bulletin, 59:27-50.

Lucas, S.G. 2000. Pathological aetosaur armor from the Upper Triassic of Germany. Stuttgarter Beiträge zur Naturkunde Serie B (Geologie und Paläontologie), 281:1-6.

Lucas, S.G., Hunt, A.P., Heckert, A.B., and Spielmann, J.A. 2007. Global Triassic tetrapod biostratigraphy and biochronology: 2007 status. New Mexico Museum of Natural History and Science Bulletin, 41:229-240.

Mader, D. 2014. Reptiles - bones - clinical considerations. Proceedings of the Association of Reptile and Amphibian Veterinarians, Orlando, FL, 78-85.

Mann, P.C., Montali, R.J., and Bush, M. 1982. Mycobacterial osteomyelitis in captive marsupials. Journal of the American Veterinary Medical Association, 181:1331-1333.

Marsh, A.D., Parker, W.G., Stockli, D.F., and Martz, J.W. 2019. Regional correlation of the Sonsela Member (Upper Triassic Chinle Formation) and detrital U-Pb zircon data from the Sonsela Sandstone bed near the Sonsela Buttes, northeastern Arizona, USA, support the presence of a distributive fluvial system. Geosphere, 15:1128-1139. https://doi.org/10.1130/GES02004.1

Marshall, C., Brinkman, D.B., Lau, R., and Bowman, K. 1997. Fracture and osteomyeltiis in PII of the second pedal digit of Deinonychus antirrhopus (Ostrom) an Early Cretaceous "raptor" Dinosaur. Palaeontological Association Abstracts, 42nd Meeting, 39:16.

Martz, J.W. and Parker, W.G. 2017. Revised formulation of the Late Triassic land vertebrate "faunachrons" of western North America: Recommendations for codifying nascent systems of vertebrate biochronology, p. 39-125. In Zeigler, K.E. and Parker, W.G. (eds.), Terrestrial Depositional Systems: Deciphering complexities through multiple stratigraphic methods. Elsevier, Amsterdam. https://doi.org/10.1016/B978-0-12-803243-5.00002-9

McCrea, R.T., Tanke, D.H., Buckley, L.G., Lockley, M.G., Farlow, J.O., Xing, L., Matthews, N.A., Helm, C.W., Pemberton, S.G., and Breithaupt, B.H. 2015. Vertebrate ichnopathology: pathologies inferred from dinosaur tracks and trackways from the Mesozoic. Ichnos, 22:235260. https://doi.org/10.1080/10420940.2015.1064408.

McWhinney, L.A., Rothschild, B.M., and Carpenter, K. 2001. Posttraumatic chronic osteomyelitis in Stegosaurus dermal spikes, p. 141-156. In Carpenter, K. (ed.), The armored dinosaurs. Indiana University Press, Bloomington.

Mehl, M.G. 1928. The Phytosauria of the Wyoming Triassic. Denison University Bulletin, Journal of the Scientific Laboratories, 23:141-172.

Milner, A.R.C., Kirkland, J.I., and Birthisel, T.A. 2006. The geographic distribution and biostratigraphy of Late Triassic-Early Jurassic freshwater fish faunas of the southwestern United States. New Mexico Museum of Natural History and Science Bulletin, 37:522-529.

Molnar, R.E. 2001. Theropod paleopathology: a literature survey, p. 337-363. In Tanke, D.H. and Carpenter, K. (eds.), Mesozoic vertebrate life: new research inspired by the paleontology of Philip J. Currie. Life of the Past. Indiana University Press, Bloomington.

Montali, R.J., Bush, M., Cromie, R., Holland, S.M., Maslow, J.N., Worley, M., Witebsky, F.G., and Phillips, T.M. 1998. Primary Mycobacterium avium complex infections correlate with lowered cellular immune reactivity in Matschie's tree kangaroos (Dendrolagus matshiei). Journal of Infectious Diseases, 178:1719-1725. https://doi.org/10.1086/314517 
Moodie, R.L. 1917. Studies in paleopathology. Part I. General considerations of the evidences of pathological conditions found among fossil animals. Annals of Medical History, 1:374-393.

Moodie, R.L. 1918. Paleontological evidences for the antiquity of disease. The Scientific Monthly, 7(3):265281.

Moodie, R.L. 1922. The paleopathology of the parasuchians. Science, 56:417.

Moodie, R.L. 1926. Excess callus following fracture of the fore foot in a Cretaceous dinosaur. Annals of Medical History, 8:73-77.

Munevar, C., Moore, B.A., Gleeson, M.D., Ozawa, S.M., Murphy, C.J., Paul-Murphy, J.R., and Leonard, B.C. 2019. Acremonium and Trichosporon fungal keratoconjunctivitis in a leopard gecko (Eublepharis macularius). Veterinary Ophthalmology, 22:928-932. https://doi.org/10.1111/vop.12700

Murry, P.A. 1989. Microvertebrate fossils from the Petrified Forest and Owl Rock Members (Chinle Formation) in Petrified Forest National Park and vicinity, Arizona, p. 249-277. In Lucas, S.G. and Hunt, A.P. (eds.), Dawn of the Age of Dinosaurs in the American Southwest. New Mexico Museum of Natural History, Albuquerque.

Olson, E.J. and Carlson, C.S. 2017. Bones, joints, tendons, and ligaments, p. 967, 989-990. In McGavin, M.D. and Zachary, J.F. (eds.), Pathologic Basis of Veterinary Disease. Elsevier, St. Louis.

Parker, W.G. 2007. Reassessment of the aetosaur 'Desmatosuchus' chamaensis with a reanalysis of the phylogeny of the Aetosauria (Archosauria: Pseudosuchia). Journal of Systematic Palaeontology, 5:1-28. https://doi.org/10.1017/S1477201906001994

Parker, W.G. and Martz, J.W. 2011. The Late Triassic (Norian) Adamanian-Revueltian tetrapod faunal transition in the Chinle Formation of Petrified Forest National Park, Arizona. Earth and Environmental Science Transactions of the Royal Society of Edinburgh, 101(Special Issue 34):231-260. https://doi.org/10.1017/S1755691011020020

Parker, W.G. 2018. Redescription of Calyptosuchus (Stagonolepis) wellesi (Archosauria: Pseudosuchia: Aetosauria) from the Late Triassic of the Southwestern United States with a discussion of genera in vertebrate paleontology. PeerJ, 6:e4291. https://doi.org/10.7717/peerj.4291

Parrish, J.M. 1986a. Locomotor adaptations in the hind limb and pelvis of the Thecodontia. Hunteria, 1(2):3-35.

Parrish, J.M. 1986b. Structure and function of the tarsus in the phytosaurs (Reptilia: Archosauria), p. 35-43. In Padian, K. (ed.), The beginning of the age of dinosaurs: Faunal change across the Triassic-Jurassic boundary. Cambridge University Press, Cambridge.

Porta, D.J. 2005. Biomechanics of impact injury, p. 279-310. In Rich, J., Dean, D.E., and Powers, R.H. (eds.), Forensic Medicine of the Lower Extremity. Humana Press

Ramsay, E.C., Daniel, B.B., Tryon, B.W., Merryman, J.I., Morris, P.G., and Bemis, D.A. 2002. Osteomyelitis associated with Salmonella enterica ss arizonae in a colony of ridgenose rattlesnakes (Crotalus willardi). Journal of Zoological Wildlife Medicine, 33:301-310. https://doi.org/10.1638/1042-7260(2002)033[0301:OAWSES]2.0.CO;2

Rasmussen, C., Mundil, R., Irmis, R.B., Geisler, D., Gehrels, G.E., Olsen, P.E., Kent, D.V., Lepre, C., Kinney, S.T., Geissman, J.W., and Parker, W.G. 2021. U-Pb zircon geochronology and depositional age models for the Upper Triassic Chinle Formation (Petrified Forest National Park, Arizona, USA): Implications for Late Triassic paleoecological and paleoenvironmental change. GSA Bulletin, 133(3-4): 539-558. https://doi.org/10.1130/B35485.1

Rega, E.A. and Brochu, C.A. 2001. Paleopathology of a mature Tyrannosaurus rex skeleton. Journal of Vertebrate Paleontology, 21(sup. 3):92A.

Richard, S.M., Reynolds, S.J., Spencer, J.E., and Pearthree, P.A. 2002. Digital graphics files for the Geologic Map of Arizona, a representation of Arizona Geological Survey Map 35, v. 1.0, Digital Geologic Map DGM-17. Arizona Geological Survey.

Rothschild, B. and Tanke, D.H. 2005. Theropod paleopathology: State-of-the-art review, p. 351366. In Carpenter, K. (ed.), The Carnivorous Dinosaurs. Indiana University Press, Bloomington.

Rothschild, B.M. Molnar, R.E., and Sebes, J.I. 1997a. Mycobacteriosis in the Pliocene. Annals of Internal Medicine, 127:168-169.

Rothschild, B.M., Tanke, D.H., and Carpenter, K. 1997b. Tyrannosaurus suffered gout. Nature, 387:357. https://doi.org/10.1038/387357a0

Rothschild, B.M. 1997. Dinosaurian paleopathology, p. 426-448. In Farlow, J.O. and BrettSurman, M.K. (eds.), The Complete Dinosaur. University of Indiana Press, Bloomington. 
Rothschild, B.M. and Martin, L.D. 2006. Skeletal impact of disease. New Mexico Museum of Natural History and Science, 33, Albuquerque.

Sander, P.M. 1992. The Norian Plateosaurus bonebeds of central Europe and their taphonomy. Palaeogeography, Palaeoclimatology, Palaeoecology, 93:255-299. https://doi.org/10.1016/0031-0182(92)90100-J

Sawyer, G.T. and Erickson, B.R. 1998. Paleopathology of the Paleocene crocodile Leidyosuchus (= Borealosuchus) formidabilis. Science Museum of Minnesota Scientific Monograph, 4:1-38.

Schoch, R.R. 2011. Tracing Seeman's dinosaur excavation in the Upper Triassic of Trossingen: his field notes and the present status of the material. Palaeodiversity, 4:245-282.

Senter, P. and Juengst, S.L. 2016. Record-breaking pain: the largest number and variety of forelimb bone maladies in a theropod dinosaur. PLOS One, 11(2):e0149140. https://doi.org/10.1371/journal.pone.0149140

Sereno, P.C. 1991. Basal archosaurs: phylogenetic relationships and functional implications. Society of Vertebrate Paleontology Memoir, 2:1-53. https://doi.org/10.1080/02724634.1991.10011426

Stewart, J.H., Poole, F.G., and Wilson, R.F. 1972. Stratigraphy and origin of the Chinle Formation and related Upper Triassic strata in the Colorado Plateau region. United States Geological Survey Professional Paper, 690:336.

Stocker, M.R. 2010. A new taxon of phytosaur (Archosauria: Pseudosuchia) from the Late Triassic (Norian) Sonsela Member (Chinle Formation) in Arizona, and a critical reevaluation of Leptosuchus Case, 1922. Palaeontology, 53:997-1022. https://doi.org/10.1111/j.1475-4983.2010.00983.x

Stocker, M.R. 2012. A new phytosaur (Archosauriformes, Phytosauria) from the Lot's Wife Beds (Sonsela Member) within the Chinle Formation (Upper Triassic) of Petrified Forest National Park, Arizona. Journal of Vertebrate Paleontology, 32:573-586. https://doi.org/10.1080/02724634.2012.649815

Stocker, M.R. and Butler, R.J. 2013. Phytosauria. Geological Society, London, Special Publications, 379:91-117. https://doi.org/10.1144/SP379.5

Stocker, M.R., Zhao, L.-J., Nesbitt, S.J., Wu, X.-C., and Li, C. 2017. A short-snouted, Middle Triassic phytosaur and its implications for the morphological evolution and biogeography of Phytosauria. Scientific Reports, 7:46028. https://doi.org/10.1038/srep46028

Sullivan, C. 2010. The role of the calcaneal "heel" as a propulsive lever in basal archosaurs and extant monitor lizards. Journal of Vertebrate Paleontology, 30:1422-1432. https://doi.org/10.1080/02724634.2010.501450

Tanke, D.H. and Currie, P.J. 2000. Head-biting behavior in theropod dinosaurs: paleopathological evidence. Gaia, 15:167-184.

Tanke, D.H. and Rothschild, B.M. 2002. Dinosores: an annotated bibliography of dinosaur paleopathology and related topics-1838-2001. Bulletin of the New Mexico Museum of Natural History and Science, 20:1-96.

Thompson, K. 2007. Bones and joints, p. 1-185. In Maxie, M.G. (ed.), Pathology of domestic animals. Elsevier.

Viana, L. and Marques, E.J. 2005. Haemogregarine parasites (Apicomplexa: Hapatozoidae) in Caiman crocodilus yacare (Crocodilia: Alligatoridae) from Pantanal, Corumbá, MS. Brazil Revista Brasileira de Parasitologia Veterinaria, 14:173-175.

Vittore, C.P. and Henderson, M.D. 2013. Brodie abscess involving a tyrannosaur phalanx: imaging and implications, p. 223-236. In Parrish, J.M., Molnar, R.E., Currie, P.J., and Koppelhus, E.B. (eds.), Tyrannosaurid Paleobiology. Indiana University Press, Bloomington.

Wang, L.H., Wu, C.F., Rajasekaran N., and Shin Y.K. 2019. Loss of tumor suppressor gene function in human cancer: an overview. Cellular Physiology and Biochemistry, 51:2647-2693. https://doi.org/10.1159/000495956

Weishampel, D.B. and Chapman, R.E. 1990. Morphometric study of Plateosaurus from Trossingen (Baden-Württemberg, Federal Republic of Germany), p. 43-52. In Carpenter, K. and Currie, P.J. (eds.), Dinosaur Systematics: Approaches and Perspectives. Cambridge University Press, Cambridge.

Westphal, F. 1976. Phytosauria, p. 99-120. In Kuhn, O. (ed.), Handbuch der Paläoherpetologie: Thecodontia. Handbuch der Paläoherpetologie/Encyclopedia of Paleoherpetology. Gustav Fischer Verlag, Stuttgart. 
Witzmann. F., Schwarz-Wings, D., Hampe, O., Fritsch, G., and Asbach, P. 2014. Evidence of spondyloarthropathy in the spine of a phytosaur (Reptilia: Archosauriformes) from the Late Triassic of Halberstadt, Germany. PLOS One 9(1): e85511. https://doi.org/10.1371/journal.pone.0085511

Wolff, E.D.S., Salisbury, S.W., Horner J.R., and Varricchio D.J. 2009. Common avian infection plagued the tyrant dinosaurs. PLOS One 4(9): e7288. https://doi.org/10.1371/journal.pone.0007288

Woodward, H.N., Rich, T.H., and Vickers-Rich, P. 2018. The bone microstructure of polar "hypsilophodontid" dinosaurs from Victoria, Australia. Scientific Reports, 8:1162. https://doi.org/10.1038/s41598-018-19362-6

Xing, L., Rothschild, B.M., Randolph-Quinney, P.S., Wang, Y., Parkinson, A.H., and Ran, H. 2018. Possible bite-induced abscess and osteomyelitis in Lufengosaurus (Dinosauria: Sauropodomorph) from the Lower Jurassic of the Yimen Basin, China. Scientific Reports, 8:5045. https://doi.org/10.1038/s41598-018-23451-x

Zeigler, K.E., Lucas, S.G., and Heckert, A.B. 2002. The Late Triassic Canjilon quarry (Upper Chinle Group, New Mexico) phytosaur skulls: evidence of sexual dimorphism in phytosaurs. New Mexico Museum of Natural History and Science Bulletin, 21:179-188.

Zeigler, K.E., Heckert, A.B., and Lucas, S.G. 2003a. An illustrated atlas of the phytosaur (Archosauria: Parasuchidae) postcrania from the Upper Triassic Snyder quarry (Petrified Forest Formation, Chinle Group). New Mexico Museum of Natural History and Science Bulletin, 24:89-103.

Zeigler, K.E., Lucas, S.G., and Heckert, A.B. 2003b. Variation in the Late Triassic Canjilon quarry (Upper Chinle Group, New Mexico) phytosaur skulls: evidence of sexual dimorphism. Paläontologische Zeitschrift, 77:341-351. https://doi.org/10.1007/BF03006946 


\title{
APPENDIX 1
}

Letter from Guy Hazen to John Reeside detailing the collection of the specimen that would become USNM 18313.
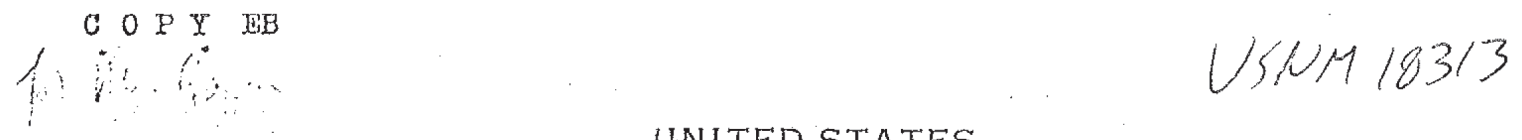

\author{
UNITED STATES \\ DEPAR'TMENT OF THE INTERIOR \\ GEOLOGICN SURVEY \\ P. 0. Box 2270 \\ pucson, Axizona.
}

Oct. 28,1948

Dr. John B. Reeside, Jx.

Chief', Section of Paleontology and Stratigrapliy

327 U. S. National Museum.

Washington, D.C.

Dear Dr. Heeside:

I have finghed wating the phytosaur fossil and have put the boxes in storage whil we receive shipping instructions A jist is enclosed shoming the womb ant and woight of each box.

A Ionger tine wat talen for the excavation as it was larger and cane was takex on every bone uncovered. The armos plate kept me from working as raptaly as on a akeleton not having this extra bone material.

A certified jurvice for the Axizona Lumber and Supply Co. is enclosed for crating lumber. A few other jtems that I paid are show on my. expense account. I am not submitting bills for some other supplies that I purchased such as alcohol, additional plaster of paxis besides that listed on ry expense account, and for expenses in connection with the use of my personal car. Some extra on my per diem takes care of those things.

I started work on excatating the phytosaur on Sept. 13. Some work had been done preceding this, duxing the month of July. It was a 50-50 gamble as to whether the remains were still burisd or had been eroded away. Some limb and toe bones may have eroded out and some may still lie beneath the bank. The remains were somewhat disturbed by strean action as the faw was separated from the skull by several feet. I had to destroy some vertebra, ribs and armor plate so as to be able to remove portions small enough to handle. I placed many ribs in paper sections. Most of them can be assembled, if need be, by fitting each piece to other pieces. If I had cast all of these it would have taken much longer.

I was unable to get labor as needed at the start to remove overburden. It became ten feet deep by the vime all was removed. There was some delay because of hard rains during the period I was removing the bone material. 
Dr. Reeside, $J x$.

$0 \mathrm{c}, 28,1948$

I did not receive is letter in agard to using gum instead of shellac, as the postmaster ati Sit. Johns forwarded it to my address at Kingman, Arizona. I did not get ft till I had completed the

If more Triassic age fossil reptile matexia.l is desixed, I am sure more material would be avajlable jo one were to put in more time in the St. Johns area. In my stady of the geology there for the Ground Water ivision I noticed nany places which raght produce if one dug into
the foumation.

the club Mosses and phytosaur skeleton came from the same horizon as in all the chin and Lepodrendron plant matertal. This horizon continues

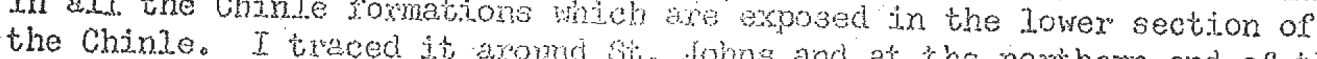
Petrified National hon thound 60 , foms and at the nothern end of the channel of a slow morions. Mhis fornetion appears to have been the a lung fish are found thromosing mex. Traces of other reptile and

There are other loceltitias in intizona where fossil manmal. remains can bo secured. One of these $1 . s$ a quarry on the Big Sandy, southeast of Kingman. Mr. Childs latick had a party including myself working for three winters there. He gave up worling there a year before the wax as he had decided he had enough material from that locality. Much more material could be secured there but at some spots the overburden is too great to get the material out at a reasonable cost. There is a great variety of maminal and bird bone to be found there. The age is upper Pliocene.

A few spectinens of a large horse and also carnel jaws and palates of late Pleistocene age can be picked up at a lake deposit south of Searchlight, Nevada. This locality has also limb bones but they are so fragile that one can blow the bone away. It lies in diatomaceous earth.

On the San Pedro near Mammoth, Arizona there is a locallty where more upper. Pliocene mammal remains were found. We worked in there two winters. All in all $I$ have wcolked in thirty field localities in Califomia, Arizona and Nevada gathering fossil remains for Mr. Childs Frick, of the American Museum of" Notural. History, New York City. Other localities I know of I have never worked.

During Norember. I will be working for the Ground Water Division near Bouse. It would be best to address any communications to me to P. O. Box 2270, Tucson, Arizoni, and they wijl be forwarded to me in the field.

$$
\begin{aligned}
& \text { Very truly yours, } \\
& \text { /s/ Guy E. Hazen } \\
& \text { Sr. Geologic Aide }
\end{aligned}
$$

P. S. A bill for transfer and storage will be submitted later. Wy salary chargesfor the entire job amount to $\$ 372.18$. G.E.H. by M.S. 


\section{APPENDIX 2}

Description of the measured section "St. Johns South" in Figure 2.

Section measured 18 May, 2008 by Appalachian State University Students (A. Ahlström, A. George, J. Mitchell, J. Norman, W. Sautter) under the direction of A.B. Heckert.

\begin{tabular}{|c|c|c|}
\hline Unit & $\begin{array}{l}\text { Petrified Forest Formation } \\
\text { Sonsela Member }\end{array}$ & $\begin{array}{l}\text { Thickness } \\
\quad \text { (in m) }\end{array}$ \\
\hline \multirow[t]{3}{*}{13} & $\begin{array}{l}\text { Conglomerate and sandstone; sandstone matrix is grayish orange (10YR7/4), medium-coarse } \\
\text { grained, moderately poorly sorted, subangular sublitharenite that is weakly calcareous; } \\
\text { conglomerate is extraformational chert and quartzite clasts, subrounded to rounded, up to } \sim 10 \mathrm{~cm} \\
\text { diameter; clast-supported; poorly indurated; forms a brown slope across top of hill. }\end{array}$ & 3.6 \\
\hline & Unconformity (Tr-4 unconformity of Lucas, 1993)/erosional base & \\
\hline & Blue Mesa Member & \\
\hline 12 & $\begin{array}{l}\text { Mudstone; grayish yellow green ( } 5 G Y 7 / 2) \text { with some dusky blue green (5BG3/2) and grayish red } \\
\text { purple (5RP4/2) mottles. }\end{array}$ & 2.35 \\
\hline 11 & $\begin{array}{l}\text { Mudstone, grayish purple (5P4/2) with yellowish gray (5Y8/1) mottles; not calcareous; bentonitic; } \\
\text { popcorn weathering; forms uppermost purple stripe. }\end{array}$ & 8.0 \\
\hline 10 & $\begin{array}{l}\text { Mudstone, grayish red purple ( } 5 \mathrm{RP} 4 / 2) \text { with mottles of light greenish gray }(5 \mathrm{GY} 8 / 1) \text {; weakly } \\
\text { calcareous; includes a horizon of brownish gray (5YR8/1) highly calcareous concretions at top of } \\
\text { unit. }\end{array}$ & 2.5 \\
\hline 9 & $\begin{array}{l}\text { Sandstone; sandstone is light greenish gray }(5 \mathrm{GY} 8 / 1) \text { with grayish purple }(5 \mathrm{P} 4 / 2) \text { mottles; } \\
\text { sandstone is fine-medium grained, rounded, moderately sorted litharenite to lithic wacke; includes } \\
\text { pebble-sized }(\sim 2 \mathrm{~mm}) \text { rounded mudstone rip-ups, not calcareous. In outcrop forms a green-purple- } \\
\text { green sandwich; upper fossiliferous layer (including past excavations) }\end{array}$ & 2.6 \\
\hline 8 & $\begin{array}{l}\text { Mudstone; grayish red purple (5RP4/2) with mottles of yellowish green }(5 \mathrm{GY} 87 / 2) \text {; slightly silty; } \\
\text { includes yellow green }(5 \mathrm{GY} 7 / 2) \text { concretionary layer at top that weathers brown with mottles of } \\
\text { grayish red purple. Forms second prominent purple band locally. }\end{array}$ & 2.2 \\
\hline 7 & $\begin{array}{l}\text { Mudstone, grayish purple (5P4/2) to very dusky purple (5P2/2) with mottles of grayish yellow green } \\
\text { (5GY7/2); bentonitic; calcareous; popcorn weathering; forms lowest prominent purple band. }\end{array}$ & 5.6 \\
\hline \multirow[t]{2}{*}{6} & $\begin{array}{l}\text { Slightly silty mudstone; medium gray (N5) with bluish white (5B9/1) mottles; not calcareous; } \\
\text { popcorn weathering; grades into unit } 7 \text {; locally has fossiliferous green sandstones }\end{array}$ & 4.6 \\
\hline & Bluewater Creek Formation & \\
\hline 5 & $\begin{array}{l}\text { Slightly silty mudstone; dark reddish brown (10R3/4), weakly calcareous, forms uppermost red } \\
\text { band. }\end{array}$ & 3.6 \\
\hline 4 & $\begin{array}{l}\text { Slightly silty mudstone, medium gray (N5) with light greenish gray ( } 5 \mathrm{GY} 8 / 1) \text {, very dusky red purple } \\
\text { (5RP2/2) and moderate yellowish brown (10YR5/4) mottles; calcareous; forms greenish band with } \\
\text { steep slope. }\end{array}$ & 2.45 \\
\hline 3 & $\begin{array}{l}\text { Thin sandstone ( } 3 \mathrm{~A}) \text { overlain by mudstone }(3 \mathrm{~B}) \text {; mudstone is dusky red }(5 \mathrm{R} 3 / 4) \text { with light greenish } \\
\text { gray }(5 \mathrm{G} 8 / 1) \text { mottles; silty; not calcareous; forms reddish layer above sandstone; basal sandstone } \\
\text { is very pale green } 910 \mathrm{G} 8 / 2) \text { fresh, weathers to dark reddish brown (10R3/4); fine- to medium- } \\
\text { grained, subrounded, moderately well sorted micaceous litharenite; very calcareous; some soft- } \\
\text { sediment deformation. }\end{array}$ & $2.45-2.75$ \\
\hline 2 & $\begin{array}{l}\text { Silty mudstone; pale red ( } 5 \mathrm{R} 6 / 2) \text { with light greenish gray ( } 5 \mathrm{GY} 8 / 1) \text { mottles, slightly calcareous; } \\
\text { forms reddish slope mantled with sandstone debris }\end{array}$ & 3.6 \\
\hline 1 & $\begin{array}{l}\text { Sandstone; yellowish gray }(5 \mathrm{Y} 8 / 1) \text { fresh; weathers to pale red }(10 \mathrm{R} 6 / 2) \text { and grayish red }(10 \mathrm{R} 4 / 2) \text {; } \\
\text { fine- to very-fine grained, rounded, well sorted micaceous litharenite; ripple laminated; locally floors } \\
\text { arroyo }\end{array}$ & $2.5+$ \\
\hline
\end{tabular}

